\title{
Extent of low-accumulation 'wind glaze' areas on the East Antarctic plateau: implications for continental ice mass balance
}

\author{
T.A. SCAMBOS, ${ }^{1}$ M. FREZZOTTI, ${ }^{2}$ T. HARAN, ${ }^{1}$ J. BOHLANDER, ${ }^{1}$ J.T.M. LENAERTS, ${ }^{3}$ \\ M.R. VAN DEN BROEKE, ${ }^{3}$ K. JEZEK, ${ }^{4}$ D. LONG, ${ }^{5}$ S. URBINI, ${ }^{6}$ K. FARNESS, ${ }^{4}$ \\ T. NEUMANN, ${ }^{7}$ M. ALBERT, ${ }^{8}$ J.-G. WINTHER ${ }^{9}$ \\ ${ }^{1}$ National Snow and Ice Data Center, University of Colorado, Boulder, Boulder, CO, USA \\ E-mail: teds@nsidc.edu \\ ${ }^{2}$ ENEA-CRE, Casaccia, Rome, Italy \\ ${ }^{3}$ Institute for Marine and Atmospheric Research, Utrecht University, Utrecht, The Netherlands \\ ${ }^{4}$ Byrd Polar Research Center, The Ohio State University, Columbus, OH, USA \\ ${ }^{5}$ Department of Electrical Engineering, Brigham Young University, Provo, UT, USA \\ ${ }^{6}$ Istituto Nazionale di Geofisica e Vulcanologia, Rome, Italy \\ ${ }^{7}$ NASA Goddard Space Flight Center, Greenbelt, MD, USA \\ ${ }^{8}$ Thayer School of Engineering, Dartmouth College, Hanover, NH, USA \\ ${ }^{9}$ Norwegian Polar Institute, Tromsø, Norway
}

\begin{abstract}
Persistent katabatic winds form widely distributed localized areas of near-zero net surface accumulation on the East Antarctic ice sheet (EAIS) plateau. These areas have been called 'glaze' surfaces due to their polished appearance. They are typically $2-200 \mathrm{~km}^{2}$ in area and are found on leeward slopes of ice-sheet undulations and megadunes. Adjacent, leeward high-accumulation regions (isolated dunes) are generally smaller and do not compensate for the local low in surface mass balance (SMB). We use a combination of satellite remote sensing and field-gathered datasets to map the extent of wind glaze in the EAIS above $1500 \mathrm{~m}$ elevation. Mapping criteria are derived from distinctive surface and subsurface characteristics of glaze areas resulting from many years of intense annual temperature cycling without significant burial. Our results show that $11.2 \pm 1.7 \%$, or $950 \pm 143 \times 10^{3} \mathrm{~km}^{2}$, of the EAIS above $1500 \mathrm{~m}$ is wind glaze. Studies of SMB interpolate values across glaze regions, leading to overestimates of net mass input. Using our derived wind-glaze extent, we estimate this excess in three recent models of Antarctic SMB at 46-82 Gt. The lowest-input model appears to best match the mean in regions of extensive wind glaze.
\end{abstract}

\section{INTRODUCTION}

Low temperatures, low snow accumulation and a surface climate dominated by near-continuous, dry inversion-driven airflow leads to a complex interaction between snow, wind and topography on the East Antarctic ice sheet (EAIS) plateau. This interaction has important effects on the local surface net mass balance in undulating regions of the ice sheet (areas having topography of one to tens of meters relief, at horizontal scales of a few hundred meters to a few tens of kilometers). Features such as megadunes, snow-glaze areas and local accumulation highs are manifestations of this interaction typical of East Antarctica (Fahnestock and others, 2000; Frezzotti and others, 2002a,b). This windtopography interaction creates a continuum of snow erosional/depositional effects that control blue-ice exposure as well as local ( $\sim 10 \mathrm{~km}$ scale and less) accumulation rates for the West Antarctic and Greenland ice sheets (e.g. Goodwin, 1990; Hoen and Zebker, 2000; Winther and others, 2001; King and others, 2004; Van den Broeke and others, 2006), and probably grade into some aspects of snow redistribution on ice fields and smaller ice caps.

Most of the Antarctic ice sheet has a snow/firn cover of about 70-100 m thickness, transitioning with depth into ice. In blue-ice areas, ice is exposed on the surface and there is no covering of firn/snow. This is because wind and sublimation can ablate much more snow/firn than is accumulated by annual solid precipitation, causing a persistent strong negative surface mass balance (SMB) that removes the firn. Blue-ice areas occur in mountainous regions and at katabatic wind confluence areas in steeply sloping and near-coastal regions. Exposed blue ice covers $\sim 1 \%$ of the Antarctic ice sheet (Winther and others, 2001). Ablation rates in blue-ice areas decrease with increasing distance from the ice-sheet edge, with negative values of SMB from -500 to $-30 \mathrm{~kg} \mathrm{~m}^{-2} \mathrm{a}^{-1}$ (Bintanja and Van den Broeke, 1995). In contrast, wind-glazed areas are regions where wind and sublimation removes about the same amount as the annual solid precipitation total, creating a hiatus in accumulation as the surface ice flows across the wind-glazed area. Their SMB is close to nil ( -20 to $\left.20 \mathrm{~kg} \mathrm{~m}^{-2} \mathrm{a}^{-1}\right)$.

Wind-glazed areas are far more extensive on the EAIS surface than blue ice, as we show in this study. The primary characteristic of wind-glaze surfaces from the perspective of this study is their near-zero SMB, which leads to distinctive surface and subsurface characteristics that can be mapped from space. Because the regions have been largely unrecognized and are generally too small to be resolved by climate models, their presence represents local lows in accumulation estimates that are not represented in current surface mass-balance grids. We review the characteristics and formation of wind-glaze regions from published literature and supporting field observations conducted for this study. We then discuss the satellite remote-sensing measurements we use to conduct an EAIS-wide mapping of 

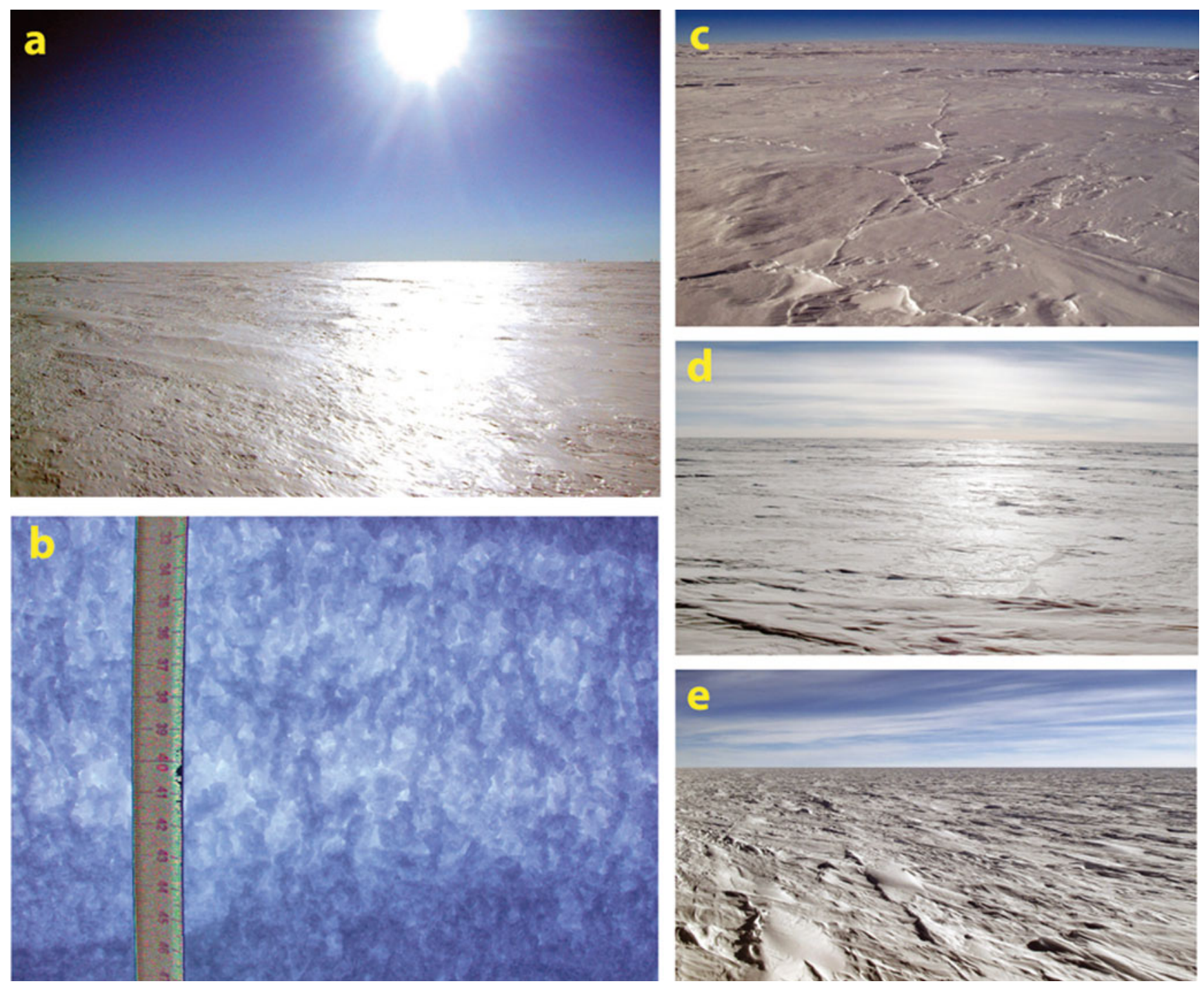

Fig. 1. Surface and subsurface characteristics of wind-glaze regions in East Antarctica. (a) Wind-glaze region near $82^{\circ} \mathrm{S}, 110^{\circ} \mathrm{E}$ (near TAMSeis Camp) on 23 November 2002, showing bright forward scattering of wind-polished snow surface. (b) Backlit snow-pit photograph in wind-glaze region between megadunes, showing coarse recrystallized grains $\left(80.24^{\circ} \mathrm{S}, 124.5^{\circ} \mathrm{W}\right.$, Megadunes Camp, January 2004$)$; centimeter scale is shown on left side of image. (c) Thermal(?) cracks typical of permanent wind-glaze areas (X-shaped pattern of fine ridges in foreground) at $84.2^{\circ} \mathrm{S}, 20.7^{\circ} \mathrm{E}$ on 4 January 2009. (d) Wind-glaze area near $88.1^{\circ} \mathrm{S}, 2.2^{\circ} \mathrm{W}$ on 25 December 2008. (e) Typical sastrugi patterns adjacent to wind-glaze areas (few $\mathrm{km}$ south of (c)). (c-e) photographs taken during Norway-US International Polar Year (IPY) Science Traverse, 2008/09 season.

wind-glaze regions, and present the mapped extent. Finally, we estimate the net effect of the regions on past estimates of snow accumulation on the EAIS. The presence of wind glaze over a significant fraction of the high EAIS surface leads to a significant revision of the total mass input to East Antarctica. This impacts mass-balance estimates based on the mass budget approach.

\section{FIELD CHARACTERISTICS OF WIND-GLAZE REGIONS}

Wind-glaze areas are irregular to elongated patches of a few hundred meters to a few tens of kilometers in linear dimensions, characterized by a wind-polished glazed surface overlying a coarsely recrystallized firn layer (Fig. 1a; Wantanabe, 1978; Goodwin, 1990; Frezzotti and others, 2002a; Albert and others, 2004). They occur almost exclusively in East Antarctica. The features are observed generally above $\sim 1500 \mathrm{~m}$ elevation as well as in confluence areas of katabatic winds (e.g. David Glacier, Mertz-Cook catchment basins) (Scarchilli and others, 2010), and up to within a few tens of kilometers of the EAIS ice divide at 3600-3800 m elevation (Watanabe, 1978; this study). Wind polishing by blowing snow occurs primarily from autumn to early spring (Scarchilli and others, 2010), when katabatic wind speed and persistence is greatest (Parish and Bromwich, 1987). The polished glaze surface transmits more solar energy into the underlying firn than an unmodified snow surface, allowing solar radiation to penetrate and warm the subsurface layer. This in turn drives a greater upward transport of water vapor, followed by condensation of the vapor against the underside of the glaze surface. Fujii and Kusunoki (1982) showed that this underplating of the surface crust occurred between August and January, caused by vapor transport and condensation. The process is slow during winter months, but increases during late spring and summer due to higher vapor pressure as the firn temperature increases. 


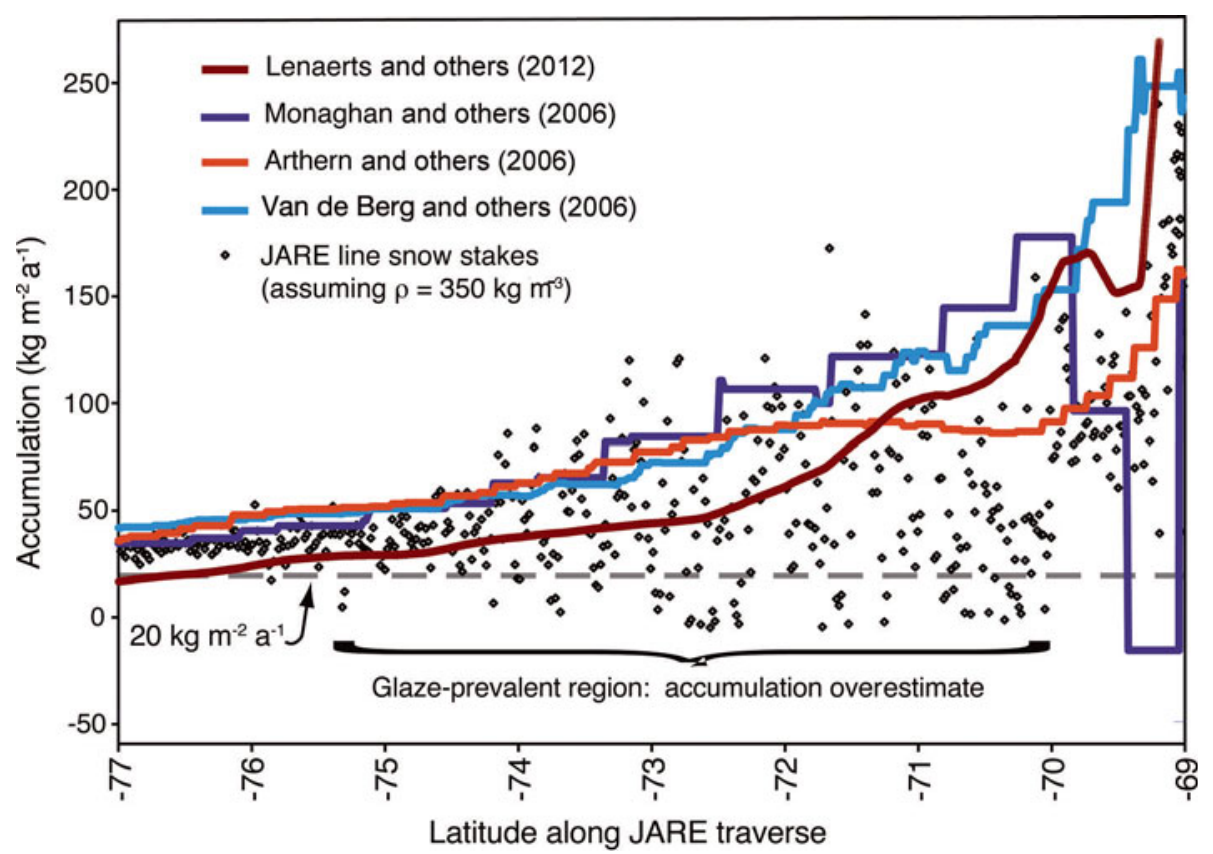

Fig. 2. Mean snow accumulation from the JARE stake line, 1993-2007 (14 years) for stations S16 to MD738 converted to net SMB assuming a snow density of $350 \mathrm{~kg} \mathrm{~m}^{-3}$. Profiles along the stake line from four recent regional net surface mass-balance estimates are shown for comparison. Dashed line shows the surface mass-balance threshold for glaze extent used in this study, $20 \mathrm{~kg} \mathrm{~m}^{-2} \mathrm{a}^{-1}$.

During late spring and summer, the large temperature gradient between the solar-heated surface layer and colder firn at depth also causes extensive depth-hoar formation (Fig. 1b; Albert and others, 2004; Courville and others, 2007). This creates coarse $(\sim 0.5$ to $1.0 \mathrm{~cm})$ cup-shaped ice crystals (e.g. DenHartog, 1959; Giovinetto, 1963; Goodwin and others, 1994; Gay and others, 2002; Courville and others, 2007). Repeated seasonal thermal cycling of the upper firn with low or zero accumulation results in a several meters thick layer of these coarse recrystallized grains, with almost no remnant of layering or depositional density variations remaining (as in Fig. 1b). Repeated thermal cycling also leads to the formation of surface cracks, presumably by thermal expansion and contraction of the upper snow/firn layer (Fig. 1c; Watanabe, 1978; Frezzotti and others, 2002a; Albert and others, 2004; Courville and others, 2007). These cracks are several meters deep and divide the surface into irregular polygons a few meters across. In late summer, radiative cooling of the uppermost surface layer leads to formation of a surface frost, by condensation of local atmospheric vapor onto the snow surface (e.g. Shuman and Alley, 1993). This gives the glaze surface a more diffuse specular reflection than in spring (Fig. 1d), and changes its appearance in remote-sensing data. Late-summer/early-fall surface frost formation is widespread, and not exclusively associated with wind glaze.

Formation of wind-glaze surfaces appears to result from locally increased average inversion wind speed due to an increase in local surface slope in the downwind direction (Frezzotti and others, 2002a). Because inversion flow is a gravity-driven drainage of a cold inversion air layer, an increase in surface slope over a distance of a few times the inversion layer thickness (typically 100-300 m; Connolley, 1996) can accelerate the flow. Increased wind speeds lead to an increase in blowing-snow transport, and an increase in surface and within-airstream sublimation of snow due to adiabatic heating and compression (e.g. Neumann and others, 2005; Scarchilli and others, 2010), that over the annual cycle removes all or almost all of the precipitated or wind-deposited snow that may temporarily accumulate. Instrumental observations integrated with a snow accumulation survey (snow radar, firn core, remote sensing) suggest that the combined processes of blowing-snow sublimation and snow transport remove up to $50 \%$ of precipitation in some coastal and slope convergence areas (Scarchilli and others, 2010). However, armoring of the surface by the wind-glaze crust prevents significant ablation of the surface over a range of moderate wind speeds. For example, glazed surfaces (and not blue ice) are widespread in the David Glacier and Lambert Glacier basins where mean wind speeds are $>11 \mathrm{~m} \mathrm{~s}^{-1}$ during most of the year (Goodwin and others, 1994; Frezzotti and others, 2005). Field measurements in regions of wind glaze show few areas of significant negative SMB (e.g. Japanese Antarctic Research Expedition (JARE); see Fig. 2; Motoyama and others, 2008).

In regions adjacent to wind-glaze surfaces, as winddirection surface slope flattens or even reverses, a local high in accumulation may occur in the form of a large transverse dune or series of dune/glaze pairs. For a narrow range of wind-direction slopes, the alternation between transverse glaze stripes and accumulating ridges can become self-reinforcing, leading to long trains of glazedune pairs called megadunes. In this case, the accumulation stripe modifies the regional mean slope such that the accreting face is relatively flat or reversed with respect to the wind direction, and the back side steepens to the point of supporting faster local winds and therefore glaze formation. Accumulating surfaces are generally rough (Watanabe, 1978; Goodwin, 1990; Fahnestock and others 2000; Fig. 1e) with well-sintered fine-grained snow in complexly eroded sastrugi forms. Wind-glaze areas are very flat and smooth, with few if any sastrugi forms. Thus, the differences in surface texture amplify the accumulating nature of the dune stripes and the reduced accumulation of 
the glaze areas, as the near-surface blowing snow interacts with these distinct roughness variations.

The accumulation areas can in part offset the local low in accumulation represented by the glaze surface. However, at two megadune field sites, $81.24^{\circ} \mathrm{S}, 124.5^{\circ} \mathrm{E}$ and $75.5^{\circ} \mathrm{S}$, $129.5^{\circ} \mathrm{E}$ (Frezzotti and others, 2002b; Albert and others, 2004; Scambos and others, 2006), and over long-term snow stake fields (e.g. JARE and the Chinese Antarctic Research Expedition (CHINARE) (Motoyama and others, 2008; Ding and others, 2011)), the adjacent accumulation highs do not compensate for the near-zero glaze region extent relative to regional accumulation estimates or nearby field measurements (e.g. JARE line; Fig. 2). At the megadune field site, two accumulation measurements using $\beta$-radiation detection of nuclear bomb fallout in shallow firn cores were made near the highest-accumulation portion of the dune crests. The measured values (33.5 and $42.0 \mathrm{~kg} \mathrm{~m}^{-2} \mathrm{a}^{-1}$ ) are at or below the accumulation value attributed to the entire region (glaze and dune crest together) for several recent continent-wide SMB models (Arthern and others, 2006; Monaghan and others, 2006; Scambos and others, 2006; Van de Berg and others, 2006; Courville and others, 2007). However, for both the JARE line and the megadune field sites, the recent RACMO2 Antarctic regional atmospheric climate model (Lenaerts and others, 2012) is closer to the net total SMB as measured ( $\sim 20 \mathrm{~kg} \mathrm{~m}^{-2} \mathrm{a}^{-1}$; Fig. 2$)$. We consider the estimates of these SMB models for wind-glaze areas over the entire EAIS.

While the glaze formation processes can occur for short periods in a net accumulation environment, creating a temporary wind-glaze surface, it is the long-term (decades to centuries) lack of accumulation and the persistence of a steady and locally increased katabatic flow in the steeper windswept areas that leads to extreme development of these characteristics in the near-surface firn layer. Persistence of wind intensity and direction in the EAIS is very high between 1500 and $3500 \mathrm{~m}$ elevation (Parish and Bromwich, 1987; Fahnestock and others, 2000). Although katabatic airflow patterns can dominate wind conditions in lower-elevation regions as well, intervals of cyclonic-driven winds and increased snowfall lead to a mix of surface conditions at a given site. This results in less consistent (temporally intermittent) wind-glaze surfaces, with higher net accumulation and therefore less development of recrystallized firn and an absence of thermal cracks (Goodwin, 1990).

The near-zero net accumulation of wind-glaze areas has been shown in numerous studies, most effectively by regional stake-line surveys and ground-penetrating radar (GPR) profiles. Although temporary accumulation events can occur on glaze surfaces, appearing as scattered low-relief sastrugi, these are transient on the multi-annual scale (Motoyama and others, 2008). Other means of determining net accumulation (e.g. snow-pit studies of firn layering, or isotopic-based determinations) often yield uninterpretable or misinterpreted results (e.g. Rundle, 1971). Both firn layering and isotopic variation within the ice are blurred or erased by the intense firn recrystallization. Thus past accumulation compilations from interpolation of field measurements (Vaughan and others, 1999; Giovinetto and Zwally, 2000; Arthern and others, 2006) using remote-sensing data had few valid near-zero accumulation measurements in the East Antarctic, and therefore likely interpolated across important regions of lower (near-zero) accumulation represented by wind-glaze regions. It is likely that the source datasets for the SMB compilations may have treated some sites with valid nearzero accumulation results as 'missing data' (e.g. due to inconclusive $\beta$-radiation methods, snow-pit or shallow-core layering assessments, annual chemistry or isotope variations).

The recent version of RACMO2 used by Lenaerts and others (2012) accounts for the sublimation and erosion/ deposition effects of drifting snow and increased katabatic airflow in increased slope areas. As we present below, however, these locally increased surface slopes are generally smaller in spatial scale than the true resolution of current continent-wide digital elevation models (DEMs) $(\sim 5 \mathrm{~km}$ (e.g. Bamber and others, 2009); 10 km (Liu and others, 1999)) or RACMO2 (currently $27 \mathrm{~km}$ grid spacing).

\section{REMOTE-SENSING DATASETS AND MEASUREMENT ERRORS}

We exploit the distinctive surface and subsurface character of glaze regions to map their extent at $\sim 125 \mathrm{~m}$ resolution over the entire EAIS plateau above $1500 \mathrm{~m}$ (World Geodetic System 1984 (WGS84) datum). Our investigation is limited to elevations above $1500 \mathrm{~m}$ because the area below this elevation has extensive crevassing and occasional surface melting that affects radar backscatter from satellite data (e.g. Magand and others, 2008). The two main datasets used for the mapping are C-band imaging radar backscatter from the RADARSAT-1 Antarctic Mapping Project (RAMP) and mean springtime surface optical snow grain size derived from Moderate Resolution Imaging Spectroradiometer (MODIS) data (Fig. 3a and b). To determine thresholds for the windglaze mapping algorithm, we use five sets of extensive, nearcontinuous field measurements of SMB: (1) the Norway-US Scientific Traverse of East Antarctica GPR profiles (Müller and others, 2010); (2) the JARE repeat snow stake-line measurements between 1993 and 2007 (503 stakes for 14 seasons; Motoyama and others (2008) and other references in the JARE data report series); (3) the CHINARE repeat snow stake-line measurements (528 sites, measured four times over 1997-2008; Ding and others, 2011); (4) GPR profile estimates from the megadune field site near $80.24^{\circ} \mathrm{S}$, $124.5^{\circ} \mathrm{W}$ crossing two $\beta$-radiation measurements (Scambos and others, 2006; Courville and others, 2007); and (5) GPRdetermined accumulation from a set of traverses and ice cores near Talos Dome (Frezzotti and others, 2005, 2007). Locations of the field accumulation measurements are shown in Figure 3c.

The radar backscatter dataset of the Antarctic continent has been described previously (Fig. 3a; Jezek, 2003). It is derived from a dedicated data collection campaign in September-October 1997 by the RADARSAT-1 C-band satellite synthetic aperture radar (SAR) system, having an original resolution of $25 \mathrm{~m}$. This was re-processed to a $125 \mathrm{~m}$ normalized backscatter image with a nominal radar incidence angle of $27^{\circ}$ (the center-swath incidence angle of the beam mode used for the majority of the continent). Residual speckle in the $125 \mathrm{~m}$ image, and seams due to imperfect normalization of the incidence angle, lead to a noise level of $\pm 1.1 \mathrm{~dB} \quad(1 \sigma ; \quad$ estimated from the grid value standard deviation after $2 \mathrm{~km}$ spatial scale high-pass filtering).

The near-radial pattern of the majority of the swath acquisitions for the RAMP Antarctic Mapping Mission-1 (AMM-1) data (Fig. 3a) means that the viewing direction crosses a broad range of mean wind and surface slope azimuths. Azimuthal variations in radar backscatter with 

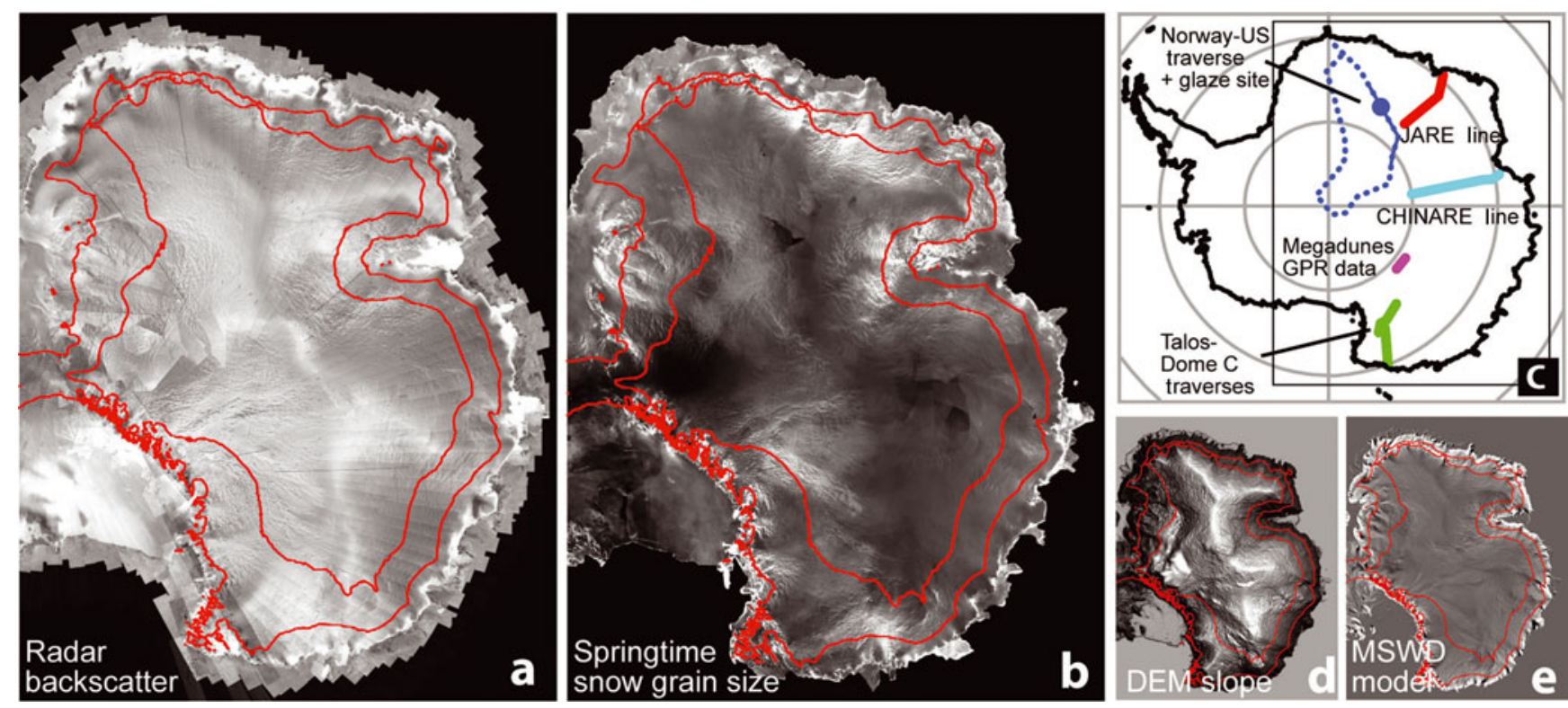

Fig. 3. Overview of datasets used for wind-glaze mapping. Study area is the region above $1500 \mathrm{~m}$ within the EAIS subscenes of RAMP backscatter (a) and MOA-derived springtime surface grain size (b). Red contours are 1500 and $2500 \mathrm{~m}$ elevation. (c) Locations of the field data used to develop the mapping relationship. (d) Absolute surface slope of the Bamber and others (2009) DEM dataset. (e) MSWD is surface slope in the annual mean wind direction, with surface slope determined from the Bamber and others (2009) DEM dataset and annual mean wind direction determined from the RACMO2/ANT model (Lenaerts and others, 2012).

respect to wind and slope over the EAIS can be significant, and appear to be consistent over time and geographical regions (Long and Drinkwater, 2000). These variations arise from changes in scattering intensity of sastrugi as the incidence direction changes from the along-wind to across-wind direction (Suhn and others, 1999), probably due to wind crust and density layer orientations. In some regions, variations are $4-8 \mathrm{~dB}$ (Suhn and others, 1999; Long and Drinkwater, 2000). However, a study comparing regions with a high percentage of wind glaze (two megadune areas) with an adjacent region that is glaze-free showed that backscatter modulation dropped significantly in the megadune regions (Lambert and Long, 2006). Moreover, windglaze areas are characterized by very sparse, low-relief sastrugi and intense subsurface recrystallization. Subsurface recrystallization textures show no variation with direction (e.g. Courville and others, 2007; Fig. 1b), and surface thermal(?) cracking is also apparently random in orientation; thus we expect little azimuthal backscatter variation in glaze areas.

Surface grain size is mapped using a normalized bandratio of the two highest-resolution bands in MODIS band 1 (at 670 and $2800 \mathrm{~nm}$, both with $250 \mathrm{~m}$ nominal resolution; Fig. 3b), with atmospheric and snow reflectance variations corrected. The band-ratio approach is based on the increased absorption of infrared light in coarser-grained ice and snow (Nolin and Dozier, 2000; Warren and Brandt, 2008). Scambos and others (2007) created a summer mean surface snow grain-size map of the entire Antarctic ice sheet for the 2003/04 season as part of the MODIS Mosaic of Antarctica (MOA) datasets using the same atmosphere-corrected bandratio technique we use here. For this study, we used image data from mid- to late spring only, including additional earlyspring images not used in the MOA compilation. We also created a new MOA-style mosaic and grain-size image for a second spring season, in late 2008. The two springtime mean optical surface snow grain-size mappings were found to emphasize the grain-size contrast between wind-glaze regions and adjacent areas relative to the spring-summer composites. We accumulated image data from over 120 MODIS scenes in each of two austral spring seasons (2003 and 2008, each spanning 5 November to 20 December) and composited the data similarly to the MOA. Sub-pixel compositing improves spatial resolution to $150-200 \mathrm{~m}$ (Scambos and others, 2007). We used the gridcell average value of the two grain-size mappings for the wind-glaze area determination.

Mapping of spring surface optical snow grain size for 2 years allows for some characterization of the interannual variability of this parameter for the study region, and provides a rough estimate of the error of the grain-size measurements. Both snow grain-size mappings show very consistent continent-wide patterns. Grain size is low $(\sim 50 \mu \mathrm{m})$ in near-coastal areas having high accumulation; moderate $(50-80 \mu \mathrm{m})$ near the ice-divide areas; and larger $(80-400 \mu \mathrm{m})$ for areas of steep slope, including extensive and distributed small wind-glaze areas, blue-ice areas and regions near nunataks and outlet glacier troughs. Mean difference between the two determinations is $10.0 \pm 27.3 \mu \mathrm{m}$ (slightly coarser overall in 2008) for the East Antarctic study area above $1500 \mathrm{~m}$. Regionally, there were differences of typically $\pm 40 \mu \mathrm{m}$ (maximum of $\pm 80 \mu \mathrm{m}$ for $\sim 10000 \mathrm{~km}^{2}$ areas). The largest region with a significant snow grain-size change is the eastern flank of the AmeryLambert basin, particularly in the Grove Mountains area. This region shows smaller 2008 grain size by $\sim 50 \mu \mathrm{m}$ relative to 2003. This variation may have impacted the CHINARE traverse results, as we discuss below. Higher 2008 grain size is observed in the Byrd Glacier catchment basin and eastern Wilkes Land. Grain size was relatively unchanged $(<20 \mu \mathrm{m}$ difference) in Dronning Maud Land, central Wilkes Land and near South Pole. We estimate local measurement noise to be $\pm 18 \mu \mathrm{m}(1 \sigma)$, derived from the histogram of a high-pass filtered version $(2 \mathrm{~km}$ equivalent 


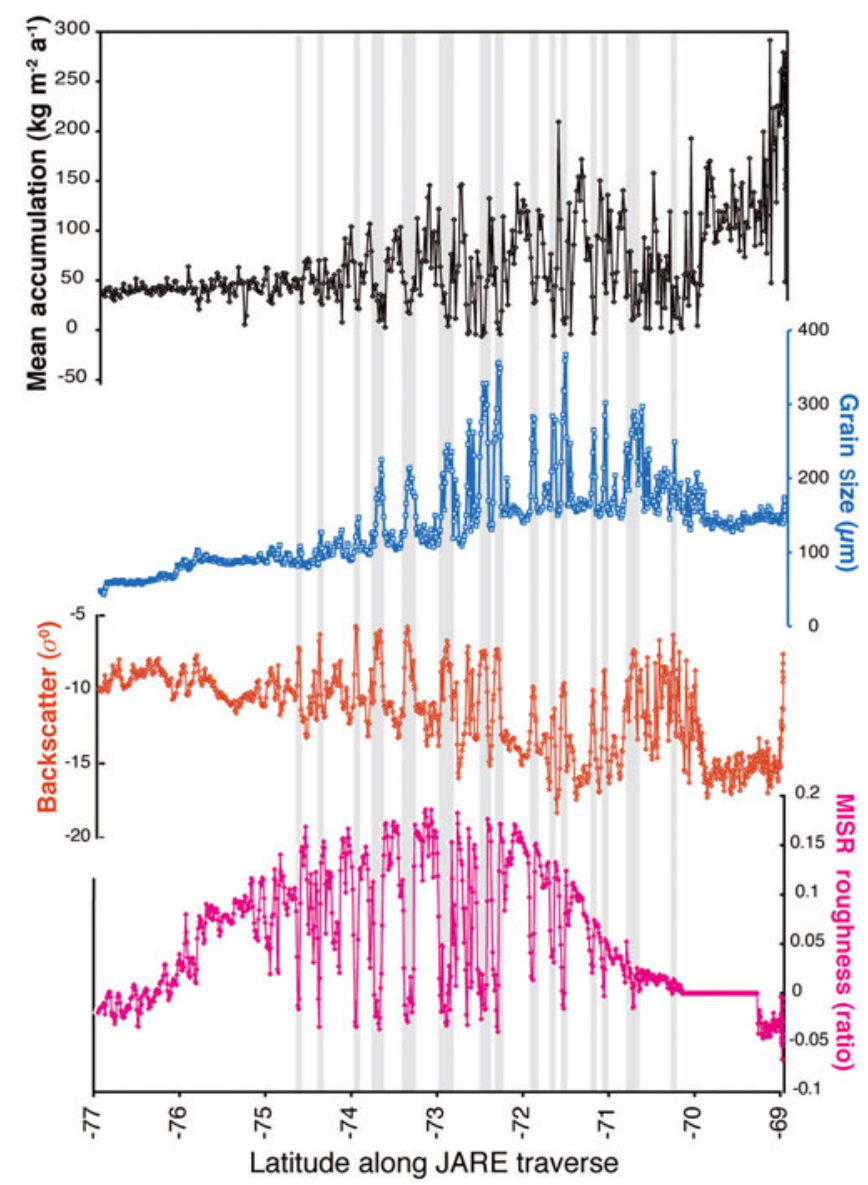

Fig. 4. Remote-sensing parameters for several satellite sensors and JARE line net surface mass-balance estimates as in Figure 2. Grey shaded vertical bars are glaze regions $\left(<20 \mathrm{~kg} \mathrm{~m}^{-2} \mathrm{a}^{-1}\right)$ along the JARE for which at least two consecutive stakes recorded reduced accumulation. Snow grain size is extracted from the MOA 2004-08 springtime grain-size grid. Backscatter is mean backscatter $\left(\sigma^{0}\right)$ along the JARE traverse from the RAMP AMM-1 compilation. Surface roughness is an approximate relative forward-scatter/ backscatter ratio derived from the Multi-angle Imaging SpectroRadiometer (MISR) instrument flown on NASA's Terra platform. The MISR backscatter estimate is the normalized ratio of the fore- and aft-looking $45^{\circ}$ off-nadir cameras (MISR's ' $C^{\prime}$ cameras); see Nolin and others (2002).

filter scale) of the two-season averaged $125 \mathrm{~m}$ snow grainsize image. However, this measurement error does not account for the interannual variability among regions, and our two mappings of grain size provide only an approximate scale for this.

Field-based studies have made a strong case that mean slope in the (mean) wind direction (MSWD) controls SMB and the formation of wind-glaze regions in the high East Antarctic plateau (Fahnestock and others, 2000; Frezzotti and others, 2005, 2007) through a local increase in mean katabatic wind speed. We created a grid of MSWD from the dot product of an absolute slope field derived from a recent high-resolution elevation model (Fig. 3d; Bamber and others, 2009) and a model-derived estimate of annual mean wind direction (from the RACMO2/ANT model; Van de Berg and others, 2006; Lenaerts and others, 2012). The MSWD grid was created at $125 \mathrm{~m}$ resolution in the same projection as the remote-sensing data, for ease of comparison (Fig. 3e), although the true resolution is significantly larger $(5-8 \mathrm{~km})$.

\section{Remote-sensing characteristics of the field SMB datasets}

The field-gathered SMB datasets we use to develop the mapping algorithm are selected to be continuous or nearcontinuous, each spanning a significant extent on the EAIS plateau, over a large latitude range within the dry snow zone and widely distributed across the study region (Fig. 3c). We selected GPR and snow stake data because these SMB data types can reliably indicate low, zero or slightly negative $S M B$, an important quality for wind-glaze mapping. ( $\beta$-radiation horizons, shallow core or pit layering, or oxygen-isotopebased SMB estimates are prone to errors or misinterpretation in wind-glaze regions; see Courville and others, 2007; Magand and others, 2007.)

The JARE traverse spans a large elevation and accumulation range, and its persistent low-accumulation sites are used to identify the major remote-sensing characteristics of the wind-glaze features relative to surrounding higheraccumulation surfaces. Local accumulation lows in the stake-line data are consistently associated with higher surface optical grain size, higher backscatter and lower surface roughness compared to adjacent stake areas (Fig. 4). We use surface grain size in particular to identify local windglaze areas relative to surroundings. Although surface roughness appears to be a further robust defining characteristic, with wind-glaze regions being significantly smoother than surrounding terrain (lowest graph in Fig. 4), further work is needed on a satellite-based roughness mapping algorithm to make it quantitative and uniform across the ice sheet. (We are evaluating a normalized ratio of the $\mathrm{C}$ fore- and aftviewing cameras on the Multi-angle Imaging SpectroRadiometer (MISR); Nolin and others, 2002.) A recently submitted manuscript supports the roughness and wind-glaze link near the Dome A region, using airborne lidar and radar backscatter data (I. Das and others, unpublished information).

We examined the transition in satellite remote-sensing characteristics in more detail using the GPR traverse of an isolated wind-glaze region in Dronning Maud Land mapped by the Norway-US traverse in 2007 (Figs 5 and 6). The test area was first identified as an anomalous low-reflectivity feature in the MOA visible-band mosaics (Fig. 5a). The feature is $\sim 14 \mathrm{~km} \times 3.5 \mathrm{~km}$, with the longer dimension perpendicular to the mean wind. Both grain size and backscatter increase significantly over the feature relative to surrounding areas (Figs $5 \mathrm{~b}$ and c). The feature lies within a band of increased MSWD, and is centered on a local MSWD maximum (Fig. $5 d$ ). Southwest of the wind-glaze feature lies a parallel pair of narrow transverse dunes, the largest being $\sim 12 \mathrm{~km} \times 1.5 \mathrm{~km}$. Both backscatter and surface grain size decrease significantly over the dunes. Depth to the traced reflector (Tambora horizon, $1815 \mathrm{CE}$ from adjacent ice cores) decreases to $4.5 \mathrm{~m}$ near the center of the feature, equating to a SMB of $8.2 \mathrm{~kg} \mathrm{~m}^{-2} \mathrm{a}^{-1}$ (Fig. 5e). Background regional SMB ranges from 26 to $35 \mathrm{~kg} \mathrm{~m}^{-2} \mathrm{a}^{-1}$. Although accumulation increases significantly within the dune region (to a peak of $67 \mathrm{~kg} \mathrm{~m}^{-2} \mathrm{a}^{-1}$ ), the extent of the locally increased accumulation is not sufficient to offset the reduced accumulation over the more extensive glaze region. Both satellite radar backscatter and surface grain size change significantly and abruptly as net SMB decreases below $20-22 \mathrm{~kg} \mathrm{~m}^{-2} \mathrm{a}^{-1}$, identifying the wind-glaze region (Fig. 6). Similar shifts are noted in the satellite remote-sensing values of the other field sites, consistently near the $20 \mathrm{~kg} \mathrm{~m}^{-2} \mathrm{a}^{-1}$ level (Fig. 7). We 

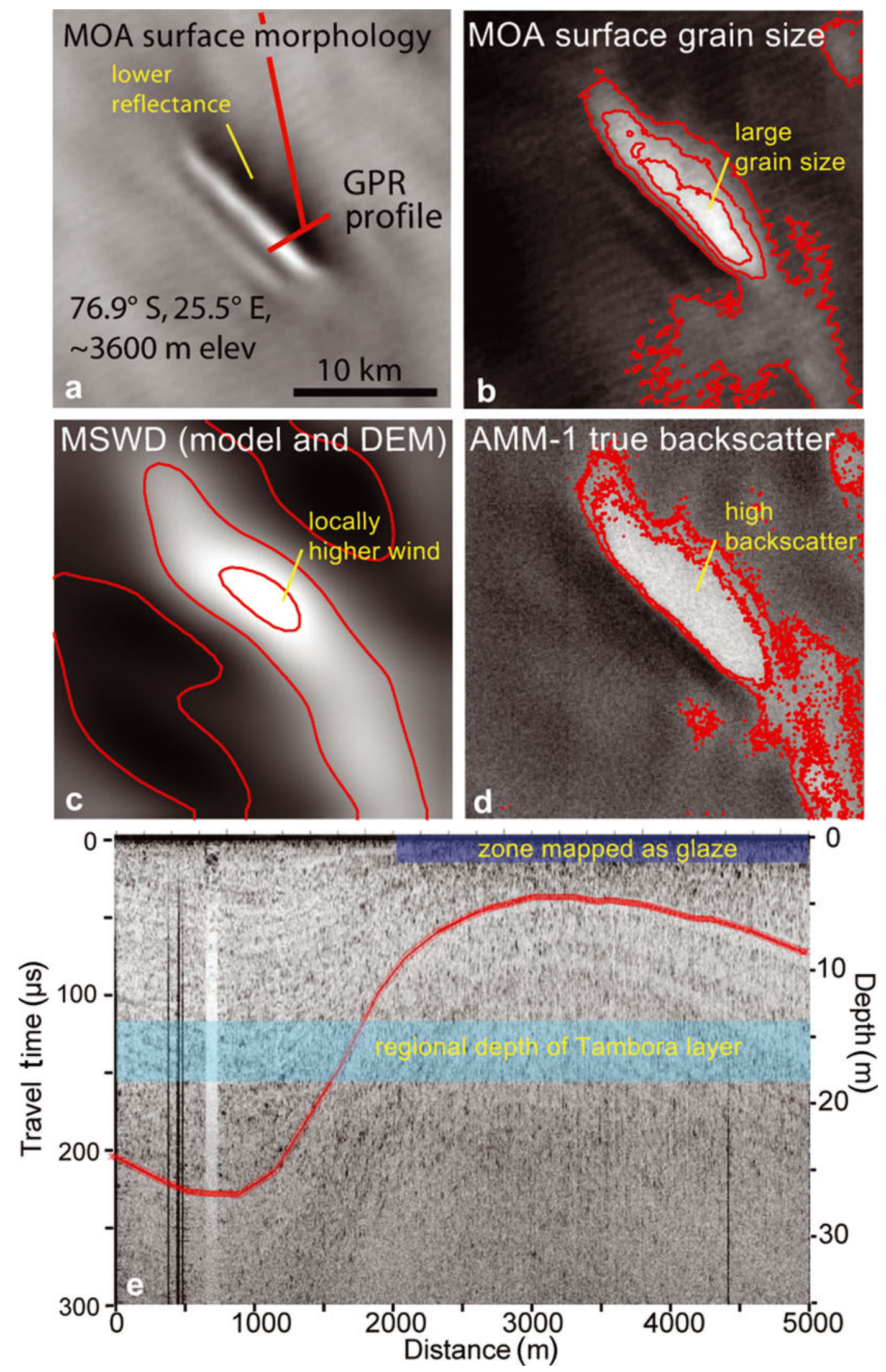

Fig. 5. Remote-sensing data and field GPR profile across a wind-glaze site in central Dronning Maud Land. (a) MODIS Mosaic of Antarctica image of the glaze site. MOA surface reflectance is relative (arbitrary units). (b) Springtime surface snow grain size from MODIS bands 1 and 2. Contour values for surface optical snow grain size are 140, 120 and $100 \mu \mathrm{m}$, background is $85-95 \mu \mathrm{m}$. (c) MSWD for the region has contour values of 0.002 and 0.004 . (d) Radar backscatter from AMM-1 compilation. Contour values for radar backscatter are -5 and $-7.5 \mathrm{~dB}$; background is generally -9 to $-11 \mathrm{~dB}$. (e) GPR profile from traverse across the site. Red trace in radar profile is the depth to the Tambora-level $(1815 \mathrm{CE})$ isochrone; cyan bar shows range of accumulation from other GPR data in the region, and purple bar shows extent of wind-glaze surface as mapped by the final algorithm. The radar profile is not corrected for surface slope. In this area, the region of $<20 \mathrm{~kg} \mathrm{~m}^{-2} \mathrm{SMB}$ is approximately bounded by the areas of $>-6.5 \mathrm{~dB}$ backscatter and $>120 \mu \mathrm{m}$ grain size. Nearly all of the mapped glaze extent lies within the 0.003 MSWD level. 


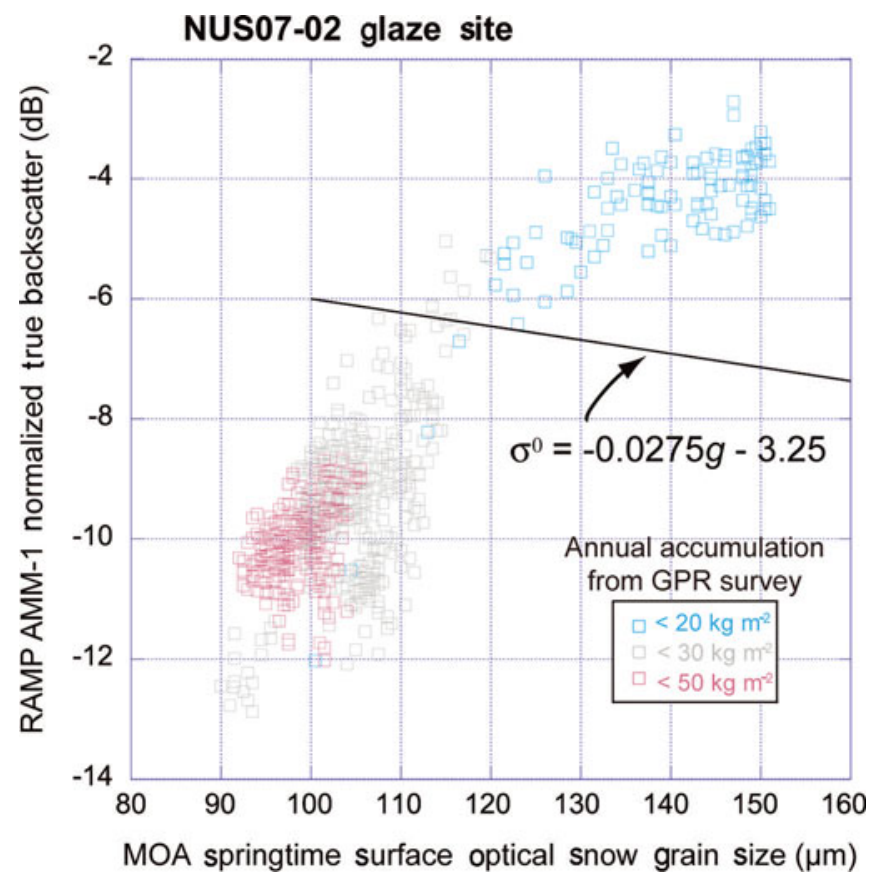

Fig. 6. Mean springtime surface optical grain size (2003 and 2008 austral springs) from MODIS data versus RADARSAT C-band backscatter along a GPR traverse across a wind-glaze region in Dronning Maud Land. Ranges of SMB derived from the GPR traverse are shown as different symbol colors. The main mapping criteria for determining wind-glaze regions derived from all field datasets are shown.

establish an empirical threshold for wind-glaze feature mapping based on a line in grain-size-backscatter space that best segregates regions with a SMB below $20 \mathrm{~kg} \mathrm{~m}^{-2} \mathrm{a}^{-1}$ from their surroundings:

$$
\begin{aligned}
b \leq 20 \mathrm{~kg} \mathrm{~m}^{-2} \mathrm{a}^{-1} \text { when } \sigma^{0} \leq & (-0.0275 \pm 0.007) g \\
& -(3.25 \pm 1)
\end{aligned}
$$

where $\sigma^{0}$ is true radar backscatter (normalized to $27^{\circ}$ incidence angle) and $g$ is springtime optical surface grain size $(\mu \mathrm{m})$. Errors in the coefficient and constant in the linear equation are controlled by the measurement errors in the satellite data. As noted for Figure 6, transitions between glaze and non-glaze physical characteristics and remotesensing values are generally abrupt.

The remote-sensing characteristics of other areas of the East Antarctic plateau above the $1500 \mathrm{~m}$ elevation threshold led us to establish other approximate criteria for wind-glaze mapping (Fig. 8). Based on data from the highest-altitude portions of the Norway-US traverse and JARE stake line, we determined that the highest ice divide and summit areas have very low surface accumulation, approaching $20 \mathrm{~kg} \mathrm{~m}^{-2} \mathrm{a}^{-1}$, and show increased radar backscatter but very low surface grain size. We attribute this to a high proportion of 'diamond dust' accumulation, and a combination of very low wind speed and significant subsurface recrystallization due to slow burial. Known blue-ice areas in the study area show a trend toward reduced backscatter and very high surface optical grain size. Past studies using band-ratio approaches to map blue-ice extent established a value of $400 \mu \mathrm{m}$ as a useful edge of blue-ice extent (Brown and Scambos, 2004); and low backscatter of blue-ice regions is attributed to specular reflection of the radar beam away from the satellite (e.g. Fahnestock and others, 1993). Very high-backscatter areas $\left(\sigma^{0}>-2 \mathrm{~dB}\right.$ ) above $1500 \mathrm{~m}$ are rare but may be associated with crevassing or refrozen surface melt layers. To eliminate these non-wind-glaze areas from our mapping we established additional criteria (Figs 7 and 8):

$$
100 \mu \mathrm{m}<g<400 \mu \mathrm{m} ; \quad \sigma^{0}<-2.0 \mathrm{~dB}
$$

Overall, these threshold characteristics seem reasonably robust across the high-elevation portions of the EAIS, but there are regional variations that suggest further climaterelated variations in accumulation and wind-glaze formation (Fig. 8). Regionally (in areas of a few thousand square kilometers) a distinctive nonlinear relationship is seen between snow grain size and radar backscatter. Windward slopes and extensive low-slope areas consistently show the lowest local backscatter and smallest surface grain size, which grades approximately linearly until reaching the (empirical) wind-glaze threshold of $20 \mathrm{~kg} \mathrm{~m}^{-2} \mathrm{a}^{-1}$. Across that threshold, with further decrease in accumulation, surface optical snow grain size increases significantly. These trends are qualitatively consistent but vary with regional altitude and regional mean accumulation (see Fig. 8), with locally higher accumulation generally leading to finer grain size and significantly higher radar backscatter for the trend. This relationship shows promise for future mapping of accumulation rate directly from high-resolution satellite remote-sensing data.

\section{Errors in glaze extent mapping}

Errors of omission and commission occur in the mapping, as is apparent in Figure 7. We estimate errors by the number of radar measurement points or stake sites that were incorrectly mapped (based on the field data) by our empirical linear relationship and the additional bounding thresholds. For sites with accumulation measurements averaged over centuries (e.g. site shown in Figs 5 and 6, and other data from the Norway-US traverse), errors in the glaze mapping are low: $0.7 \%$ (13 out of 1799 points) overall, 1.6\% mapped incorrectly as glaze (commission; 6 of 368 points) and $0.5 \%$ mapped incorrectly as non-glaze (omission; 7 of 1432). The classification errors in both cases cluster near the threshold of $20 \mathrm{~kg} \mathrm{~m}^{-2} \mathrm{a}^{-1}$, reducing their impact on estimates of reduced SMB from glaze extent. For the Talos Dome traverse data, which had significantly higher accumulation than $20 \mathrm{~kg} \mathrm{~m}^{-2} \mathrm{a}^{-1}$ at all points, there were no classification errors. For the other field measurement sites, classification errors are larger due to poorer in situ determination of accumulation and edge effects. For the JARE line (with net accumulation based on 14 years of snow stake measurements), classification errors are $26 \%$ commission (10 of 37 points) and $4.3 \%$ omission (18 of 416 points), overall $6 \%$. At the megadune site, errors were $18 \%$ commission (28 of 155 points) and $15 \%$ omission (26 of 175 points), overall 16\%; however, for this surface type, dune migration leads to thin surface layers of new accumulation underlain by former glaze surfaces, resulting in different sources for the surface grain size and backscatter properties at the dune boundaries. As discussed above, lower regional grain size along much of the CHINARE traverse may have partially affected the assessment of glaze extent there. With the relationship developed using the overall collection of field data, the CHINARE dataset has $9 \%$ errors of commission (40 of 448 points mis-mapped as glaze) overall and $45 \%$ errors of omission (36 of 80 persistently low-accumulation sites not mapped as glaze). However, if we adjust the surface grain 


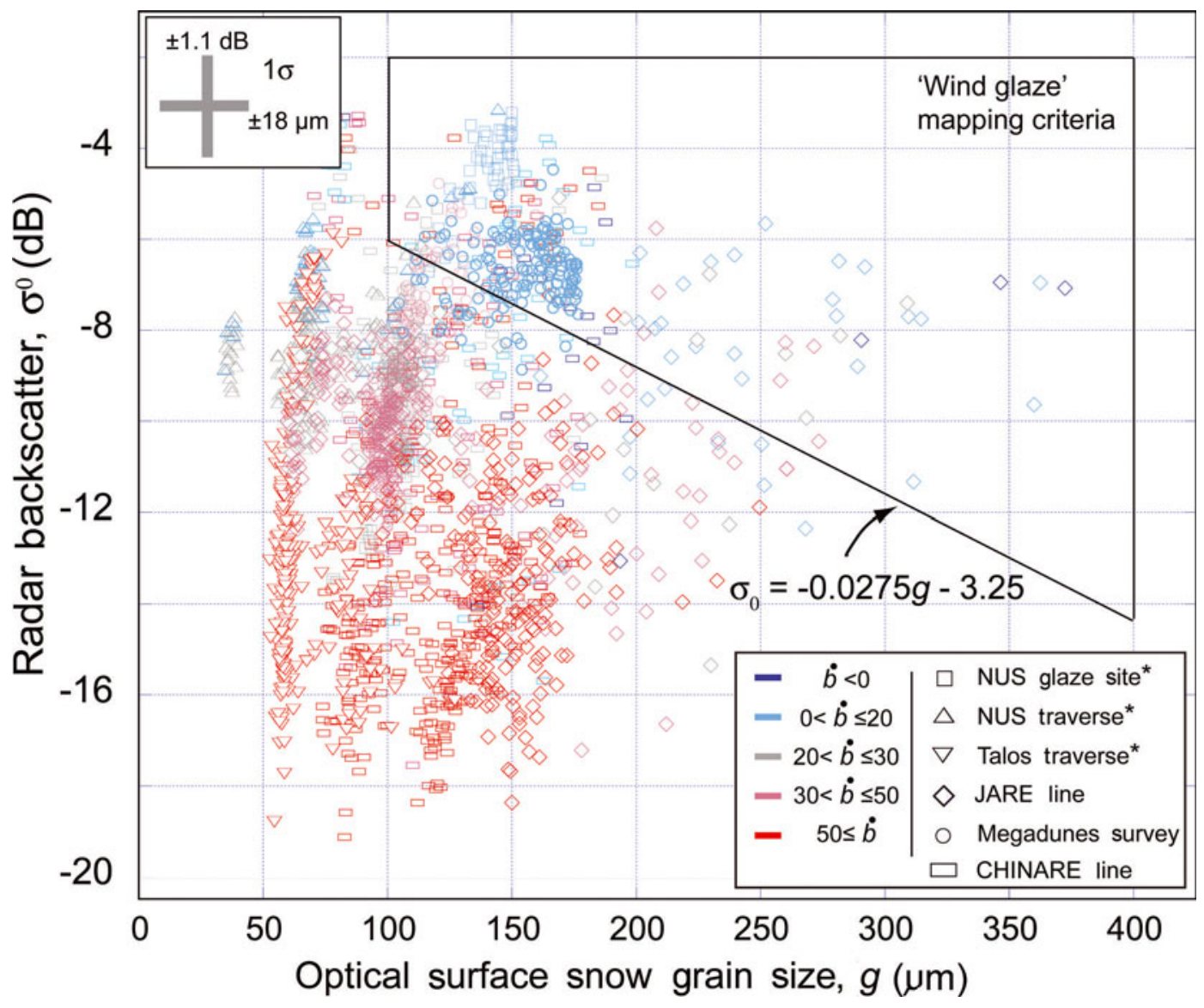

Fig. 7. MODIS-derived springtime surface optical snow grain size versus RAMP AMM-1 radar backscatter for the field measurement sites. The selection line used for estimating regional wind-glaze extent is shown, as are other thresholds used to eliminate non-glaze areas from the calculation (at grain sizes $<100$ and $>400 \mu \mathrm{m}$, and backscatter $>-2 \mathrm{~dB}$ ). Symbol color indicates SMB range; symbol type indicates SMB dataset. Asterisks next to the field SMB dataset indicate these data were subset, showing only every fifth data point for clarity.

size by $50 \mu \mathrm{m}$ (i.e. essentially eliminating the regional pattern of lower 2008 grain size) we reduce the error of omission to $34 \%$ (27 of 80 points). We adopt an estimated error of $\pm 15 \%$ for the glaze-mapped area as a combined value for omission and commission errors.

\section{RESULTS}

We now apply the equation and other criteria determined above to the entire East Antarctic plateau to estimate glaze extent using the $125 \mathrm{~m}$ gridded remotely sensed datasets. Total glaze area extent for the EAIS above $1500 \mathrm{~m}$ elevation is $950 \pm 143 \times 10^{3} \mathrm{~km}^{2}$ using the described thresholds. This is $11.2 \pm 1.7 \%$ of the total surface area at that altitude or higher (Fig. 9; Table 1). Glaze extent above $2500 \mathrm{~m}$ is $552 \pm 83 \times 10^{3} \mathrm{~km}^{2}$, or $10.0 \pm 1.5 \%$ of the surface.

Glaze is widespread across many of the major catchment basins of the EAIS. Catchments with the highest total glaze area are the Byrd-Beardmore basin, Recovery-Slessor region and Lambert Glacier. Catchments with the highest percentage of glaze area are Mawson Coast, Mertz-Cook region and the Lambert Glacier catchment. Extensive contiguous regions of glaze occur, notably in the northern Byrd-Beardmore catchment, Recovery-Slessor catchment, western Lambert basin, the Mawson Coast and upper MertzCook area. In several regions, the extensive glaze areas are truncated by our $1500 \mathrm{~m}$ elevation threshold. Additional wind-glaze areas exist for some distance below this level, mainly in confluence areas of katabatic wind (e.g. David basin; Mertz-Cook area (Frezzotti and others, 2002a; Scarchilli and others 2010); however, our selection criteria would have included increasing errors due to short-term

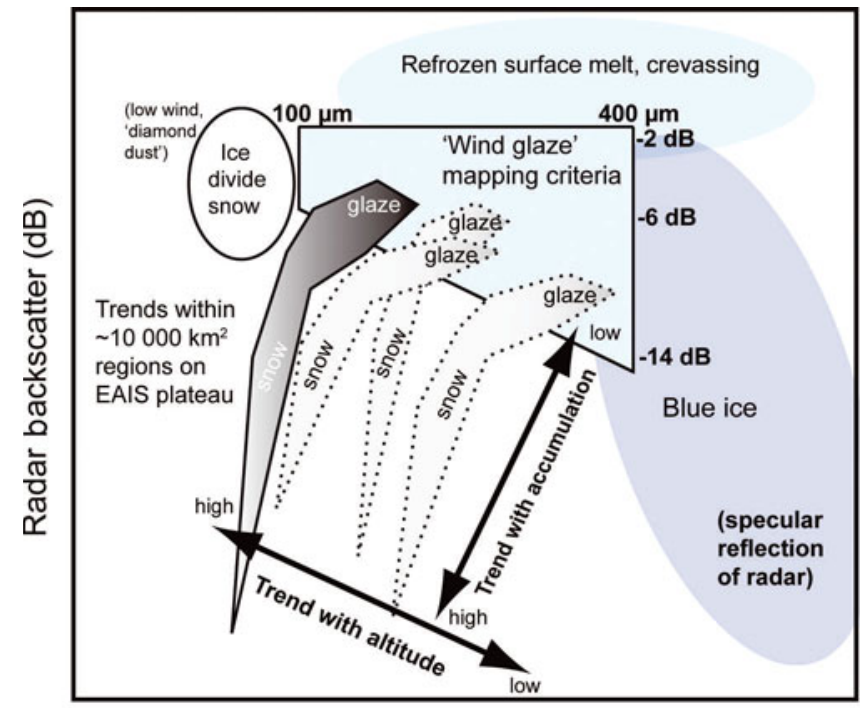

Optical surface snow grain size $(\mu \mathrm{m})$

Fig. 8. Diagram of surface optical grain size versus radar backscatter showing characteristics and trends of various surface types for the East Antarctic plateau. 


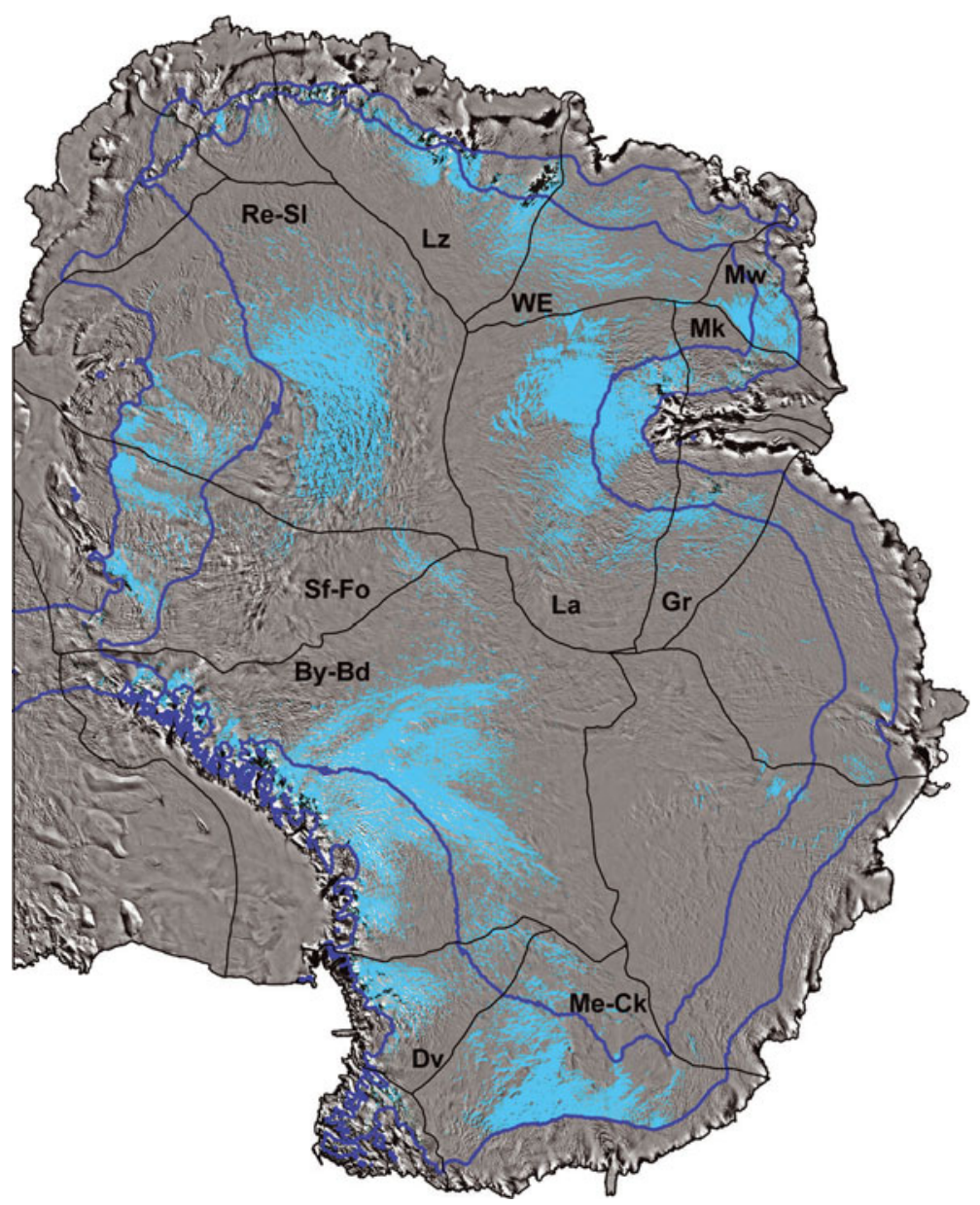

Fig. 9. Distribution of glaze regions (cyan) in East Antarctica, showing the major drainage basins for the ice sheet. The 1500 and $2500 \mathrm{~m}$ elevation contours are shown in dark blue. Drainage basins are labeled with abbreviations of local major features or research bases. Clockwise from center left: By-Bd, Byrd-Beardmore region; Sf-Fo, Support Force-Foundation region; Re-SI, Recovery-Slessor region; Lz, Lazarev Ice Shelf region; WE, West Enderby region; Mw, Mawson Coast region; Mk, MacKenzie Bay region; La, Lambert region; Gr, Grove Mountains region; Me-Ck, Mertz-Cook region; Dv, David region. See Table 1.

surface glazing, crevassing and melt-layer effects. Surface glazing was noted at lower elevations on the Talos Dome traverse (for example), but accumulation rates along the traverse remained high.

Given the widespread glaze extent, and the evidence that they represent persistent near-zero accumulation surfaces, we examine the amount of accumulation attributed to glaze areas using three recent estimates of Antarctic SMB (Figs 9 and 10; Table 1; Arthern and others, 2006; Monaghan and others, 2006; Lenaerts and others, 2012). For glaze areas above $1500 \mathrm{~m}$, a total of $46.3-82.4 \mathrm{Gta}^{-1}$ of input mass is attributed to glaze areas, with mean attributed SMB rates of $49-87 \mathrm{~kg} \mathrm{~m}^{-2} \mathrm{a}^{-1}$. For regions above $2500 \mathrm{~m}$, input mass values of $17.2-34.4 \mathrm{Gt} \mathrm{a}^{-1}$ are attributed, with mean SMB of $31-62 \mathrm{~kg} \mathrm{~m}^{-2} \mathrm{a}^{-1}$. Even with substantial extents of adjacent high-accumulation regions, it is unlikely that these overestimates can be rebalanced to the mean modeled accumulation for glaze regions. Moreover, the large contiguous regions of glaze mapped in the Byrd-Beardmore, Lambert, David, Mawson and Mertz-Cook have no high-accumulation regions of sufficient extent to offset the near-zero SMB of the mapped glaze areas.

Figure 11 examines the distribution of wind glaze as histograms of gridcells mapped as glaze relative to MSWD model values and DEM elevation (RACMO2/ANT; Bamber and others, 2009; Lenaerts and others, 2012). Glaze extent peaks at values of 0.00075-0.0016 MSWD (unitless, or $\mathrm{m} \mathrm{m}^{-1}$ ) and elevations of 2685-2900 m. These values compare well with MSWD for megadune regions (average slope of a megadune field, including glaze and accumulating dune areas, generally 0.0010-0.0016; Frezzotti and others, 2002a), but our mean value is significantly lower than the values these studies determine for individual glaze surfaces (>0.004). Our MSWD mapping is based on a satellite altimetry DEM, which has a true resolution scale of $3-8 \mathrm{~km}$ (Bamber and others, 2009). This is much coarser than the remote-sensing-based parameters, and is also a larger scale than true surface undulations. In other words, the mean slope measurements and derived MSWD are somewhat too coarse to capture the glaze areas discretely. Mean elevation for all cells mapped as glaze is $2585 \mathrm{~m}$. Wind-glaze area drops off abruptly above $3400 \mathrm{~m}$, approaching the elevation of the ice divides in the EAIS.

The Lenaerts and others (2012) SMB estimates from the RACMO2/ANT climate model are consistently lower than the other two SMB estimates, and for two of the basins (Byrd-Beardmore and David) this estimate attributes a net mass balance of $<20 \mathrm{~kg} \mathrm{~m}^{-2} \mathrm{a}^{-1}$ for glaze areas, as our study indicates (Table 1). This model modifies input snowfall with enhanced sublimation and redistribution from drifting snow, 

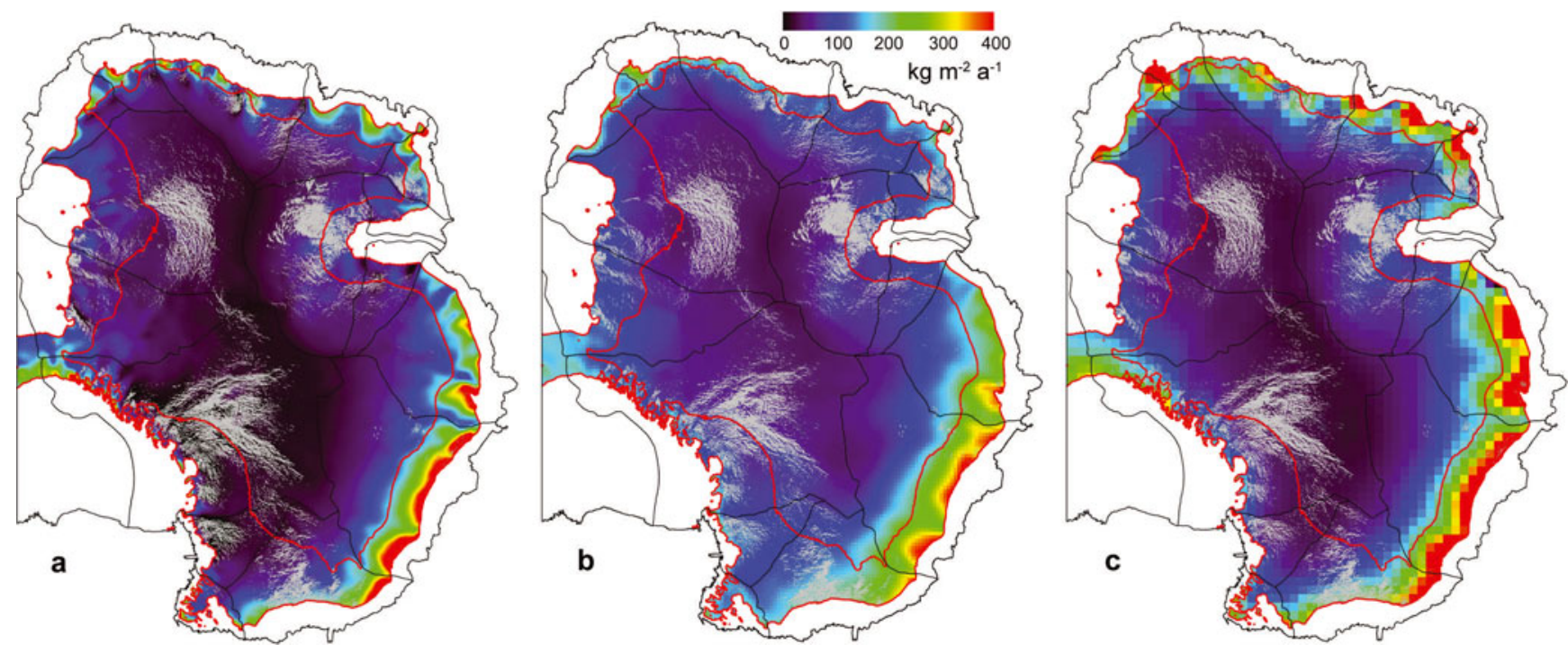

Fig. 10. Mapped wind-glaze extent (grey) plotted over three color-coded recent net SMB maps of East Antarctica: (a) Lenaerts and others (2012); (b) Arthern and others (2006); (c) Monaghan and others (2006). Drainage regions as in Figure 9; the 1500 and $2500 \mathrm{~m}$ elevation contour from Bamber and others (2009) is shown as a red line.

and benefits from a higher-resolution surface wind field model (which is driven primarily by inversion gravity-driven forcing in the upper EAIS; Van den Broeke and others, 2002). However, all three models likely attribute too great a SMB value to some of the basin regions, specifically those close to the coast: Mawson Coast, MacKenzie Bay, Mertz-Cook, and Lazarev Ice Shelf catchment regions. The implication is that net SMB in all current models of the EAIS is too high by an amount large enough to impact estimates of mass balance for the ice sheet, in these regions in particular. Specifically, mass-balance estimates based on mass budget methods should account for overestimated accumulation in the basins with the highest proportions of glaze and highest SMB attributed to glaze shown in Table 1. Elevation-changebased estimates $(\mathrm{d} H / \mathrm{d} t$, or volumetric measures of ice-sheet mass balance) or gravity-based estimates (from the Gravity Recovery and Climate Experiment (GRACE) satellite) will be relatively unaffected.

Table 1. Surface area and mass input of East Antarctica and several EAIS catchment basins, and amount of total mass input and SMB attributed to wind-glaze areas

\begin{tabular}{|c|c|c|c|c|c|c|c|c|}
\hline \multirow{3}{*}{ Region* } & \multirow{3}{*}{$\begin{array}{c}\text { Area } \\
10^{3} \mathrm{~km}^{2}\end{array}$} & \multirow{3}{*}{$\begin{array}{c}\text { Glaze area } \\
10^{3} \mathrm{~km}^{2}\end{array}$} & \multicolumn{2}{|c|}{ Arthern and others (2006) } & \multicolumn{2}{|c|}{$\begin{array}{l}\text { Estimated surface mass input } \\
\text { Monaghan and others (2006) }\end{array}$} & \multicolumn{2}{|c|}{ Lenaerts and others (2012) } \\
\hline & & & Total & Glaze $^{\S}$ & Total & Glaze $^{\S}$ & Total & Glaze $^{\S}$ \\
\hline & & & $\mathrm{Gta}^{-1}$ & $\mathrm{Gta}^{-1}$ & $\mathrm{Gta}^{-1}$ & $\mathrm{Gta}^{-1}$ & $\mathrm{Gt} \mathrm{a}^{-1}$ & $\mathrm{Gta}^{-1}$ \\
\hline EAIS $>1500 m$ & 8454.4 & $950(11.2)$ & 791.9 & $82.4(87)$ & 846.7 & $78.1(82)$ & 555.0 & $46.3(49)$ \\
\hline EAIS $>2500 m$ & 5537.6 & $552(10.0)$ & 375.6 & $34.4(62)$ & 353.8 & 30.3 (55) & 216.2 & $17.2(31)$ \\
\hline $\begin{array}{l}\text { Byrd-Beard- } \\
\text { more }\end{array}$ & 1702.8 & 285 (16.7) & 109.7 & $20.3(71)$ & 84.7 & $13.7(48)$ & 46.2 & $4.4(16)$ \\
\hline $\begin{array}{l}\text { Recovery-Sles- } \\
\text { sor }\end{array}$ & 1372.2 & $172(12.5)$ & 66.8 & $8.2(48)$ & 61.2 & $6.6(38)$ & 48.9 & $5.3(30)$ \\
\hline Lambert Glacier & 889.7 & $170(19.1)$ & 51.9 & $11.8(69)$ & 56.2 & $13.6(80)$ & 38.0 & $9.3(55)$ \\
\hline $\begin{array}{l}\text { Support/Founda- } \\
\text { tion }\end{array}$ & 678.1 & 37 (5.5) & 50.4 & $3.5(93)$ & 41.7 & $2.7(74)$ & 48.9 & $1.6(42)$ \\
\hline Mertz-Cook & 517.5 & $101(19.6)$ & 81.4 & $17.0(168)$ & 72.1 & $8.2(154)$ & 53.3 & $10.7(106)$ \\
\hline $\begin{array}{l}\text { Lazarev Ice } \\
\text { Shelf }\end{array}$ & 443.5 & $54(12.2)$ & 40.0 & $6.0(111)$ & 61.7 & $9.1(168)$ & 30.5 & $5.0(91)$ \\
\hline West Enderby & 365.4 & $30(8.2)$ & 34.1 & $2.6(86)$ & 57.3 & $3.6(121)$ & 32.5 & $2.0(66)$ \\
\hline David Glacier & 225.8 & $32(14.2)$ & 23.4 & $3.7(117)$ & 11.1 & $1.7(53)$ & 5.2 & $0.2(7)$ \\
\hline Grove Mtns & 191.0 & $12(6.5)$ & 15.7 & $1.0(82)$ & 18.0 & $1.2(93)$ & 8.7 & $0.5(42)$ \\
\hline Mawson Coast & 98.8 & $30(29.9)$ & 13.0 & $3.7(124)$ & 21.6 & $4.4(148)$ & 14.1 & $3.4(116)$ \\
\hline MacKenzie Bay & 86.9 & $5.4(6.3)$ & 9.8 & $0.7(119)$ & 12.3 & $0.8(154)$ & 7.3 & $0.4(77)$ \\
\hline
\end{tabular}

*See Figure 9 for locations and extents of regions. Elevation zone for all the catchment basins is $>1500 \mathrm{~m}$.

Percent glaze cover of the region is shown in parentheses next to glaze area amount.

*Error in glaze extent area mapping is estimated at $\pm 15 \%$.

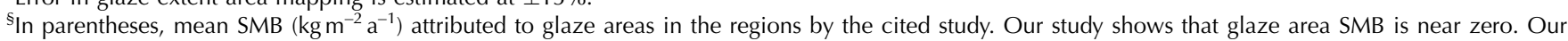
mapping threshold is $20 \mathrm{~kg} \mathrm{~m}^{-2} \mathrm{a}^{-1}$. 

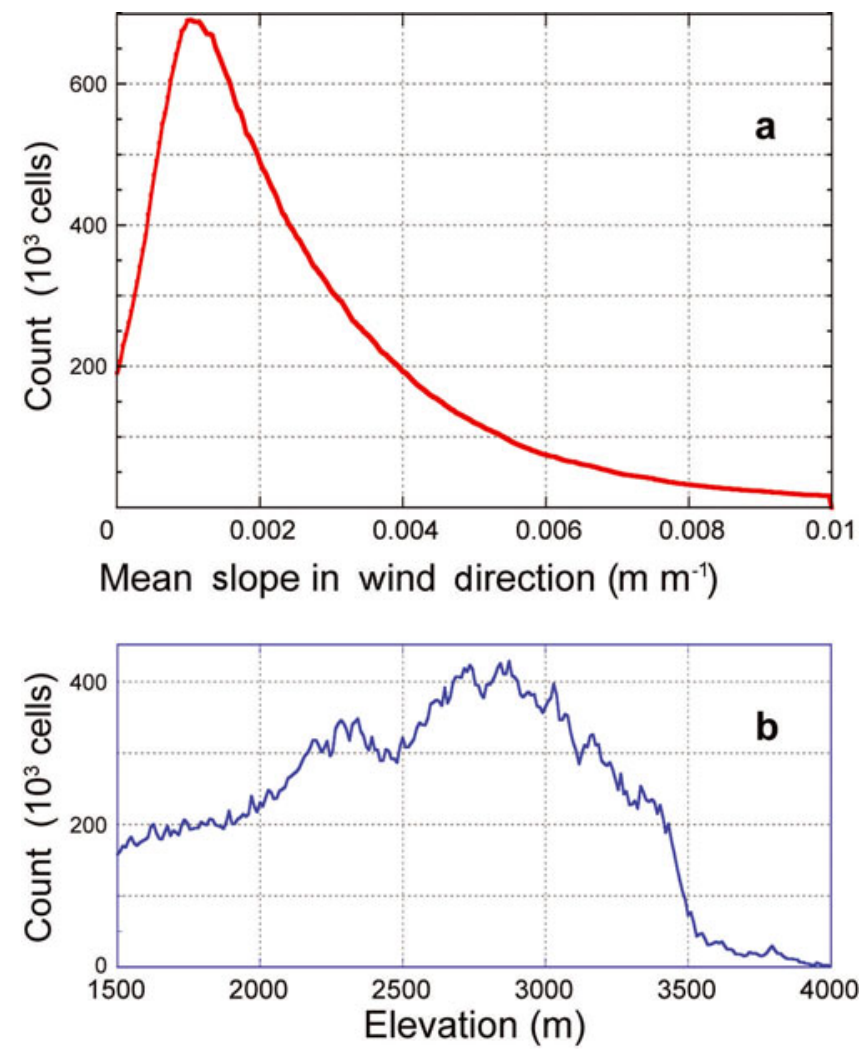

Fig. 11. Histograms of number of cells ( $125 \mathrm{~m}$ nominal scale) mapped as wind glaze as a function of (a) MSWD and (b) elevation (from Bamber and others, 2009; Lenaerts and others, 2012).

\section{DISCUSSION}

The mapping we present, and the physical characteristics used to identify wind-glaze regions, essentially describe a new surface facies type for ice sheets, as distinctive as those in Benson's (1960) landmark study. Recent studies, and studies in preparation as of this writing, have identified many extensive regions of wind glaze in the East Antarctic plateau region, and have variously attributed them to long-term 'hiatuses' in accumulation or buried ablation areas formed in past glacial epochs (Siegert and others, 2003; Wen and others, 2006; Arcone and others, 2012).

Siegert and others (2003) identify buried unconformable reflections in GPR data in the catchment regions of Byrd and Nimrod Glaciers. They note that if the missing surface layers were removed by ablation, then a large region of blue ice would be exposed, and that this may be shallowly buried beneath new accumulation. The regions identified by Siegert and others (2003) lie very close to areas mapped as extensive surface glaze here, and we infer from the new evidence we present that these areas are sites of very longterm accumulation hiatus due to the wind-glaze processes. Wen and others (2006) examined accumulation variability in the region of the ANARE (Australian National Antarctic Research Expeditions) Lambert Glacier basin traverse. Their analysis of stake accumulations over the period 1990-94 and 1998 shows high local ( $2 \mathrm{~km}$ scale) variability, with many near-zero net snow measurements, but few negative SMB sites. Further, their study identifies broad areas in the Lambert catchment system where their interpolated estimate of mean SMB falls significantly below that of the two models they use in comparison (Antarctic Mesoscale Prediction System (AMPS) and Polar fifth generation Mesoscale Model
(MM5); Powers and others, 2003; Bromwich and others, 2004). The regions of low accumulation closely approximate our mapped areas of extensive wind glaze.

Similarly, Arcone and others (2012) identify large expanses of zero-accumulation surface interspersed with local high-accumulation regions. They argue for intensified accumulation in these isolated (glaze-surrounded) regions, well above any measured accumulation rates in the literature for the area of their study (Byrd Glacier catchment), and several-fold above that required for balance of Byrd Glacier (e.g. Stearns, 2007). However, the model approach taken by Arcone and others (2012) assumes that regional accumulation values from models were accurate (specifically those from Vaughan and others, 1999; Arthern and others, 2006; Van de Berg and others, 2006), and then concludes that they underestimate regional accumulation. Stearns (2011) uses the pre-Lenaerts and others (2012) accumulation values for four major EAIS outlet glaciers and concludes that all may be impacted by overestimates of SMB in their catchments. The SMB values of Lenaerts and others (2012) greatly reduce the positive imbalance for these outlets.

The present assessment of accumulation in extensive glaze areas suggests that ice balance velocities should also be reduced in these areas. A comparison of actual velocity (measured by interferometric SAR for regional comparisons, or a GPS for point measurements) with current models of balance velocity would confirm whether glaze-prevalent regions in fact represent accumulation deficits, or are balanced by adjacent higher-accumulation regions. Far less mass input to the system (our conclusion), and the steadystate assumption (no ongoing surface elevation change) in surface balance velocity calculations leads to a reduction in the ice flow velocity needed to distribute surface infall to the margins in the ice-sheet system. However, the comparison requires a significant amount of glaze area upflow of the measurement site. The lower-elevation regions of megadune areas, or the zones of contiguous glaze shown in Figure 9, are the most likely locations where measured velocities should be considerably lower than those estimated from earlier SMB models (especially pre-Lenaertz and others, 2012).

Why should regions of wind glaze (and their adjacent accumulation highs) represent a net loss of snow mass? Many studies to date have assumed that wind redistribution of snow was a mass-conservative process, and that mass lost from windswept regions was deposited in adjacent areas of accumulation. All of the field datasets we present (Figs 2, 4 and 5, and data from the megadune field sites; Scambos and others 2006; Courville and others, 2007; Frezzotti and others 2007; Scarchilli and others, 2010) show that in fact adjacent areas of above-regional-mean accumulation are smaller in extent and insufficient to compensate for the surface loss. We attribute the net loss to adiabatic heating and drying of the inversion air layer, and the local increase in wind speed over glaze regions. The downflowing air sublimates entrained blowing snow. At the lower-elevation edge (or down-airflow edge of a steeper MSWD region), part of the entrained mass of blowing snow has been converted to water vapor, and is carried on with the katabatic flow even though the airflow slows and allows the remaining snow to accumulate in the glaze-adjacent dune. This was partially discussed by Neumann and others (2005) and is mentioned qualitatively in numerous studies. Modeling of 
this process for a glaze region, and extending the study to regional scales where glaze is prevalent, is a suitable avenue for future work.

\section{CONCLUSIONS}

Wind-glaze areas can be mapped based on their remotesensing characteristics, which are derived from unique physical characteristics due to persistent low accumulation in windswept parts of ice sheets, primarily the middle elevations of the EAIS. They are widespread, and cover extensive contiguous areas in the EAIS interior. In regions nearer the coast, all current SMB models tend to overestimate the surface mass input to glaze regions, and many recent SMB models overestimate wind-glaze mass balance in all areas. Glazed area with $\mathrm{SMB}<20 \mathrm{~kg} \mathrm{~m}^{-2} \mathrm{a}^{-1}$ represents $\sim 11 \%$ of the area above $1500 \mathrm{~m}$ and represents generally the lower limit (hiatus in accumulation) of SMB of the EAIS, excluding blue-ice areas that represent $\sim 1 \%$ of the surface (and are generally limited to coastal areas and regions adjacent to nunataks). Our analysis suggests that all current SMB models for the EAIS overestimate mass input to the ice sheet by $46-82 \mathrm{Gta}^{-1}$. Moreover, extensive wind erosion areas are present below $1500 \mathrm{~m}$, where snow precipitation is on average higher. These could not be accounted for in this paper due to the limitations of our remote-sensing analysis. Therefore, our evaluation of EAIS SMB decrease due to the extent of wind-glazed surfaces must be taken as a lower limit of the overestimation.

Inclusion of drifting-snow physics (entrained-snow sublimation) in regional climate models improves the representation of low-SMB and -ablation areas. Running these models at higher resolution ( $5 \mathrm{~km}$ or less) should resolve wind-glaze areas discretely and could potentially quantify the processes responsible for their formation and persistence.

Most important, however, are the implications for continental mass balance. Our study indicates that glaze areas are extensive enough to have a significant impact on current estimates of SMB, and therefore overall mass balance using the mass budget method (MBM; e.g. Rignot and others, 2008). The scale of the overestimate is equal to the total error reported for East Antarctica $\left( \pm 61 \mathrm{Gta}^{-1}\right.$; Rignot and others, 2008) and a large fraction of the currently reported error bars for Antarctic-wide mass balance $\left( \pm 150 \mathrm{Gta}^{-1}\right.$; Rignot and others, 2011). Moreover, the error represented by the $\mathrm{SMB}$ overestimate over wind-glaze regions moves the MBM results in the direction of GRACE-based results for Antarctica as a whole and for the East Antarctic ice sheet (Velicogna, 2009; Rignot and others, 2011). Elevationchange-based estimates $(\mathrm{d} H / \mathrm{d} t$, or volumetric measures of ice-sheet mass balance) or gravity-based estimates (from the GRACE satellite) will be relatively unaffected by these results, if performed at a decadal averaging scale.

\section{ACKNOWLEDGEMENTS}

This work was supported by NASA grants NNG04GM10G and NNX10AL42G, and US National Science Foundation grant OPP-0538495 (T.S., T.H., J.B., T.N. and M.A.). We acknowledge the ice2sea project, funded by the European Commission's 7th Framework Programme through grant No. 226375, manuscript No. ice2sea072. We thank the staff of Raytheon Polar Services, the Norsk Polarinstitutt, the field team of the Norwegian-US International Polar Year
(IPY) Scientific Traverse, and the 109th Air National Guard and Ken Borek Air for their logistical help during Antarctic fieldwork.

\section{REFERENCES}

Albert $M$, Shuman $C$, Courville $Z$, Bauer R, Fahnestock $M$ and Scambos T (2004) Extreme firn metamorphism: impact of decades of vapor transport on near-surface firn at a lowaccumulation glazed site on the East Antarctic plateau. Ann. Glaciol., 39, 73-78 (doi: 10.3189/172756404781814041)

Arcone SA, Jacobel R and Hamilton G (2012) Unconformable stratigraphy in East Antarctica: Part I. Large firn cosets, recrystallized growth, and model evidence for intensified accumulation. J. Glaciol., 58(208), 240-252 (doi: 10.3189/2012JoJ11J044)

Arthern RJ, Winebrenner DP and Vaughan DG (2006) Antarctic snow accumulation mapped using polarization of $4.3 \mathrm{~cm}$ wavelength microwave emission. J. Geophys. Res., 111(D6), D06107 (doi: 10.1029/2004JD005667)

Bamber JL, Gomez-Dans JL and Griggs JA (2009) A new $1 \mathrm{~km}$ digital elevation model of the Antarctic derived from combined satellite radar and laser data - Part 1: data and methods. Cryosphere, 3(1), 101-111

Benson CS (1960) Stratigraphic studies in the snow and firn of the Greenland ice sheet. (PhD thesis, California Institute of Technology)

Bintanja R and Van den Broeke MR (1995) The climate sensitivity of Antarctic blue-ice areas. Ann. Glaciol., 21, 157-161

Bromwich DH, Guo Z, Bai L and Chen Q (2004) Modelled Antarctic precipitation. Part I: spatial and temporal variability. J. Climate, 17(3), 427-447

Brown IC and Scambos TA (2004) Satellite monitoring of blue-ice extent near Byrd Glacier, Antarctica. Ann. Glaciol., 39, 223-230 (doi: 10.3189/172756404781813871)

Connolley WM (1996) The Antarctic temperature inversion. Int. J. Climatol., 16(12), 1333-1342

Courville ZR, Albert MR, Fahnestock MA, Cathles LM and Shuman CA (2007) Impacts of an accumulation hiatus on the physical properties of firn at a low-accumulation polar site. J. Geophys. Res., 112(F2), F02030 (doi: 10.1029/2005JF000429)

DenHartog SL (1959) Snow pit work on Little America-Victoria Land Traverse 1958-1959. The Ohio State University, Columbus, $\mathrm{OH}$ (OSU Research Foundation Report 825-2, Pt 2)

Ding $M$ and 6 others (2011) Spatial variability of surface mass balance along a traverse route from Zhongshan station to Dome A, Antarctica. J. Glaciol., 57(204), 658-666 (doi: 10.3189/002214311797409820)

Fahnestock M, Bindschadler R, Kwok R and Jezek K (1993) Greenland ice sheet surface properties and ice dynamics from ERS-1 SAR imagery. Science, 262(5139), 1530-1534

Fahnestock MA, Scambos TA, Shuman CA, Arthern RJ, Winebrenner DP and Kwok R (2000) Snow megadune fields on the East Antarctic Plateau: extreme atmosphere-ice interaction. Geophys. Res. Lett., 27(22), 3719-3722 (doi: 10.1029/1999GL011248)

Frezzotti M, Gandolfi S, La Marca F and Urbini S (2002a) Snow dunes and glazed surfaces in Antarctica: new field and remotesensing data. Ann. Glaciol., 34, 81-88 (doi: 10.3189/ 172756402781817851)

Frezzotti M, Gandolfi S and Urbini S (2002b) Snow megadunes in Antarctica: sedimentary structure and genesis. J. Geophys. Res., 107(D18), 4344 (doi: 10.1029/2001JD000673)

Frezzotti $M$ and 13 others (2005) Spatial and temporal variability of snow accumulation in East Antarctica from traverse data. J. Glaciol., 51(172), 113-124 (doi: 10.3189/ 172756505781829502)

Frezzotti M, Urbini S, Proposito M, Scarchilli C and Gandolfi S (2007) Spatial and temporal variability of surface mass balance near Talos Dome, East Antarctica. J. Geophys. Res., 112(F2), F02032 (doi: 10.1029/2006JF000638) 
Fujii $\mathrm{Y}$ and Kusunoki K (1982) The role of sublimation and condensation in the formation of ice sheet surface at Mizuho Station, Antarctica. J. Geophys. Res., 87(C6), 4293-4300 (doi: 10.1029/JC087iC06p04293)

Gay M, Fily M, Genthon C, Frezzotti M, Oerter H and Winther JG (2002) Snow grain-size measurements in Antarctica. J. Glaciol., 48(163), 527-535 (doi: 10.3189/172756502781831016)

Giovinetto MB (1963) Glaciological studies on the McMurdoSouth Pole traverse, 1960-1961. Inst. Polar Stud. Rep. 7

Giovinetto MB and Zwally HJ (2000) Spatial distribution of net surface accumulation on the Antarctic ice sheet. Ann. Glaciol., 31, 171-178

Goodwin ID (1990) Snow accumulation and surface topography in the katabatic zone of eastern Wilkes Land, Antarctica. Antarct. Sci., 2(3), 235-242

Goodwin ID, Higham M, Allison I and Ren J (1994) Accumulation variation in eastern Kemp Land, Antarctica. Ann. Glaciol., 20, 202-206

Hoen EW and Zebker HA (2000) Topography-driven variations in backscatter strength and depth observed over the Greenland Ice Sheet with InSAR. In 20th International Geoscience and Remote Sensing Symposium (IGARSS 2000), 24-28 July 2000, Honolulu, HI, USA. Proceedings, Vol. 2. Institute of Electrical and Electronic Engineers, Piscataway, NJ, 470-472

Jezek KC (2003) Observing the Antarctic ice sheet using the RADARSAT-1 synthetic aperture radar. Polar Geogr., 27(3), 197-209 (doi: 10.1080/789610167)

King JC, Anderson PS, Vaughan DG, Mann GW, Mobbs SD and Vosper SB (2004) Wind-borne redistribution of snow across an Antarctic ice rise. J. Geophys. Res., 109(D11), D11104 (doi: 10.1029/2003JD004361)

Lambert B and Long D (2006) A large-scale Ku-band backscatter model of the East-Antarctic megadune fields. In 26th International Geoscience and Remote Sensing Symposium (IGARSS 2006), 31 July-4 August 2006, Denver, CO, USA. Proceedings, Vol. 2. Institute of Electrical and Electronic Engineers, Piscataway, NJ, 3832-3834

Lenaerts JTM, Van den Broeke MR, Van de Berg WJ, Van Meijgaard E and Kuipers Munneke P (2012) A new, high-resolution surface mass balance map of Antarctica (1979-2010) based on regional atmospheric climate modeling. Geophys. Res. Lett., 39(4), L04501 (doi: 10.1029/2011GL050713)

Liu H, Jezek KC and Li B (1999) Development of an Antarctic digital elevation model by integrating cartographic and remotely sensed data: a geographic information system based approach. J. Geophys. Res., 104(B10), 23 199-23 213 (doi: 10.1029/ 1999JB900224)

Long DG and Drinkwater MR (2000) Azimuth variation in microwave scatterometer and radiometer data over Antarctica. IEEE Trans. Geosci. Remote Sens., 38(4), 1857-1870

Magand O and 6 others (2007) An up-to-date quality-controlled surface mass balance dataset for the $90^{\circ}-180^{\circ} \mathrm{E}$ Antarctica sector and 1950-2005 period. J. Geophys. Res., 112(D12), D12106 (doi: 10.1029/2006JD007691)

Magand O, Picard G, Brucker L, Fily M and Genthon C (2008) Snow melting bias in microwave mapping of Antarctic snow accumulation. Cryosphere, 2(2), 109-115 (doi: 10.5194/tc-2109-2008)

Monaghan AJ, Bromwich DH and Wang S-H (2006) Recent trends in Antarctic snow accumulation from Polar MM5 simulations. Philos. Trans. R. Soc. London, Ser. A, 364(1844), 1683-1708 (doi: 10.1098/rsta.2006.1795)

Motoyama $\mathrm{H}$ and 7 others (2008) Glaciological data collected by the 45th, 46th and 47th Japanese Antarctic Research Expedition during 2004-2007. JARE Data Rep. 308 (Glaciology 34)

Müller K and 6 others (2010) An $860 \mathrm{~km}$ surface mass-balance profile on the East Antarctic plateau derived by GPR. Ann. Glaciol., 51(55), 1-8 (doi: 10.3189/172756410791392718)

Neumann TA, Waddington ED, Steig EJ and Grootes PM (2005) Non-climate influences on stable isotopes at the Taylor Mouth,
Antarctica. J. Glaciol., 51(173), 248-258 (doi: 10.3189/ 172756505781829331)

Nolin AW and Dozier J (2000) A hyperspectral method for remotely sensing the grain size of snow. Remote Sens. Environ., 74(2), 207-216 (doi: 10.1016/S0034-4257(00)00111-5)

Nolin AW, Fetter F and Scambos T (2002) Surface roughness characterizations of sea ice and ice sheets: case studies with MISR data. IEEE Trans. Geosci. Remote Sens., 40(7), 1605-1615 (doi: 10.1109/TGRS.2002.801581)

Parish TR and Bromwich DH (1987) The surface windfield over the Antarctic ice sheets. Nature, 328(6125), 51-54

Powers JG, Monaghan AJ, Cayette AM, Bromwich DH, Kuo Y-H and Manning KW (2003) Real-time mesoscale modeling over Antarctica: the Antarctic Mesoscale Prediction System (AMPS). Bull. Am. Meteorol. Soc., 84(11), 1533-1545 (doi: 10.1175/BAMS84-11-1533)

Rignot E and 6 others (2008) Recent Antarctic ice mass loss from radar interferometry and regional climate modelling. Nature Geosci., 1(2), 106-110 (doi: 10.1038/ngeo102)

Rundle AS (1971) Snow accumulation and firn stratigraphy on the East Antarctic plateau. In Crary AP ed. Antarctic snow and ice studies II. American Geophysical Union, Washington, DC, 239-255 (Antarctic Research Series 16)

Scambos TA, Fahnestock MA, Shuman C and Haran TM (2006) Impact of megadunes and glaze areas on estimates of East Antarctic mass balance and accumulation rate change. [Abstr. C11A-1130] Am. Geophys. Union, Fall Meet.

Scambos TA, Haran TM, Fahnestock MA, Painter TH and Bohlander J (2007) MODIS-based Mosaic of Antarctica (MOA) datasets: continent-wide surface morphology and snow grain size. Remote Sens. Environ., 111(2-3), 242-257 (doi: 10.1016/ j.rse.2006.12.020)

Scarchilli C, Frezzotti M, Grigioni P, De Silvestri L, Agnoletto L and Dolci S (2010) Extraordinary blowing snow transport events in East Antarctica. Climate Dyn., 34(7-8), 1195-1206 (doi: 10.1007/s00382-009-0601-0)

Shuman CA and Alley RB (1993) Spatial and temporal characterization of hoar formation in central Greenland using SSM/I brightness temperatures. Geophys. Res. Lett., 20(23), 2643-2646

Siegert MJ, Hindmarsh RCA and Hamilton GS (2003) Evidence for a large surface ablation zone in central East Antarctica during the last Ice Age. Quat. Res., 59(1), 114-121 (doi: 10.1016/S00335894(02)00014-5)

Stearns LA (2007) Outlet glacier dynamics in East Greenland and East Antarctica. (PhD thesis, University of Maine)

Stearns LA (2011) Dynamics and mass balance estimates of four large East Antarctic outlet glaciers. Ann. Glaciol., 52(59), 116-126 (doi: 10.3189/172756411799096187)

Suhn H-G, Jezek K, Baumgartner F, Forster R and Mosley-Thompson E (1999) Radar backscatter measurements from RADARSAT SAR imagery of South Pole Station, Antarctica. In Stein TI ed. 19th International Geoscience and Remote Sensing Symposium (IGARSS '99), 28 June-2 July 1999, Hamburg, Germany. Proceedings, Vol. 5. Institute of Electrical and Electronic Engineers, Piscataway, NJ, 2360-2362

Van de Berg WJ, Van den Broeke MR, Reijmer $\mathrm{CH}$ and Van Meijgaard E (2006) Reassessment of the Antarctic surface mass balance using calibrated output of a regional atmospheric climate model. J. Geophys. Res., 111(D11), D11104 (doi: 10.1029/2005JD006495)

Van den Broeke MR, Van Lipzig NPM and Van Meijgaard E (2002) Momentum budget of the East-Antarctic atmospheric boundary layer: results of a regional climate model. J. Atmos. Sci., 59(21), 3117-3129 (doi: 10.1175/1520-0469(2002)059<3117: MBOTEA $>2.0 . C O ; 2)$

Van den Broeke M, Van de Berg WJ, Van Meijgaard E and Reijmer C (2006) Identification of Antarctic ablation areas using a regional atmospheric climate model. J. Geophys. Res., 111(D18), D18110 (doi: 10.1029/2006JD007127) 
Vaughan DG, Bamber JL, Giovinetto MB, Russell J and Cooper APR (1999) Reassessment of net surface mass balance in Antarctica. J. Climate, 12(4), 933-946 (doi: 10.1175/1520-0442(1999)012 $<0933$ :RONSMB $>2.0$. CO;2)

Velicogna I (2009) Increasing rates of ice mass loss from the Greenland and Antarctic ice sheets revealed by GRACE. Geophys. Res. Lett., 36(19), L19503 (doi: 10.1029/ 2009GL040222)

Warren SG and Brandt RE (2008) Optical constants of ice from the ultraviolet to the microwave: a revised compilation. J. Geophys. Res., 113(D14), D14220 (doi: 10.1029/2007JD009744)
Watanabe O (1978) Distribution of surface features of snow cover in Mizuho Plateau. Mem. Natl Inst. Polar Res., Special Issue 7, 154-181

Wen J, Jezek KC, Monaghan AJ, Sun B, Ren J and Huybrechts P (2006) Accumulation variability and mass budgets of the Lambert Glacier-Amery Ice Shelf system, East Antarctica, at high elevations. Ann. Glaciol., 43, 351-360 (doi: 10.3189/ 172756406781812249)

Winther J-G, Jespersen MN and Liston GE (2001) Blue-ice areas in Antarctica derived from NOAA AVHRR satellite data. J. Glaciol., 47(157), 325-334 (doi: 10.3189/172756501781832386)

MS received 13 November 2011 and accepted in revised form 22 April 2012 